\title{
World Trade Organization
}

Economic Research and Statistics Division

I NTERNATIONAL STANDARDS AND THE WTO TBT AGREEMENT: IMPROVING GOVERNANCE FOR REGULATORY ALIGNMENT

Erik Wijkström and Devin McDaniels

World Trade Organization (WTO)

Manuscript date: 19 March 2013 


\title{
International standards and the WTO TBT Agreement: I mproving governance for regulatory alignment ${ }^{1}$
}

\author{
Erik Wijkström², Devin McDaniels²
}

\begin{abstract}
The WTO TBT Agreement obliges governments to use international standards as a basis for regulation, yet leaves a degree of flexibility with respect to the choice of standard, and the manner of its use. This interplay between obligation and flexibility has given rise to tension in various fora of the WTO, including in committee work, negotiations and dispute settlement. This paper brings together these three distinct strands of WTO work to illustrate core aspects of the international standards debate at the WTO. In our analysis we first briefly outline the nature of the discipline in the TBT Agreement itself; next, we describe where and how the discussion arises in the WTO; and, finally, explore some implications of governance of international standard setting. We propose that greater regulatory alignment could be achieved through a renewed focus on the procedures of setting international standards (the how), and greater emphasis on robust technical/scientific underpinnings of such standards (the what).
\end{abstract}

Key words are: international trade, international standards, international cooperation, coherence, non-tariff barriers, technical barriers to trade, regulation

JEL Classifications: F13, F53, F55, K33, L15, L51

1 This is a working paper, and hence it represents research in progress. This paper represents the opinions of the authors, and is the product of professional research. It is not meant to represent the position or opinions of the WTO or its Members, nor the official position of any staff members. Any errors are the fault of the authors. Copies of working papers can be requested from the divisional secretariat by writing to: Economic Research and Statistics Division, World Trade Organization, Rue de Lausanne 154, CH 1211 Geneva 21, Switzerland. Please request papers by number and title. The authors welcome comments: erik.wijkstrom@wto.org or devin.mcdaniels@wto.org.

${ }^{2}$ Trade and Environment Division, World Trade Organization, Geneva, Switzerland. 


\title{
1 I NTRODUCTION
}

1.1. The WTO TBT Agreement obliges governments to use international standards as a basis for regulation, yet leaves a degree of flexibility with respect to the choice of standard, and the manner of its use. This interplay between obligation and flexibility has given rise to tension in various fora of the WTO, including in committee work, negotiations and dispute settlement. This paper brings together three distinct strands of WTO work to illustrate core aspects of the international standards debate. In our analysis we first briefly outline the nature of the discipline in the TBT Agreement itself; next, we describe where and how the discussion arises in the WTO; and, finally, explore some implications of governance of international standard setting. We propose that greater regulatory alignment could be achieved through a renewed focus on the processes of setting international standards (the how), and greater emphasis on robust technical/scientific underpinnings of such standards (the what).

\section{BETWEEN OBLI GATI ON AND POLI CY SPACE}

\subsection{The nature of the discipline}

2.1. International standards are core to the TBT Agreement. In its preamble, the Agreement recognizes the value of international standards for improving efficiency of production and facilitating international trade, as well as encourages the development of such standards. The contribution of international standardization to technology transfer to developing countries is also recognized. International standards are used by the Agreement as a means of promoting international harmonization of technical regulations, conformity assessment procedures, and national standards; in other words international standards can help promote greater regulatory alignment on a global scale.

2.2. At its heart, the TBT Agreement aims at striking a balance that is elaborated in the sixth recital of its preamble. This equilibrium has been described by the Appellate Body as: "on the one hand, the desire to avoid creating unnecessary obstacles to international trade and, on the other hand, the recognition of Members' right to regulate". ${ }^{3}$ The use of international standards helps operationalize this balance by providing a benchmark for TBT measures ${ }^{4}$ to ensure that they do not become unnecessarily trade-restrictive. With respect to technical regulations and conformity assessment procedures, the relevant articles state the following:

\begin{abstract}
"2.4 Where technical regulations are required and relevant international standards exist or their completion is imminent, Members shall use them, or the relevant parts of them, as a basis for their technical regulations except when such international standards or relevant parts would be an ineffective or inappropriate means for the fulfilment of the legitimate objectives pursued, for instance because of fundamental climatic or geographical factors or fundamental technological problems."
\end{abstract}

2.5 "... Whenever a technical regulation is prepared, adopted or applied for one of the legitimate objectives explicitly mentioned in paragraph 2 , and is in accordance with relevant international standards, it shall be rebuttably presumed not to create an unnecessary obstacle to international trade."

"5.4 In cases where a positive assurance is required that products conform with technical regulations or standards, and relevant guides or recommendations issued by international standardizing bodies exist or their completion is imminent, Members shall ensure that central government bodies use them, or the relevant parts of them, as a basis for

\footnotetext{
${ }^{3}$ WT/DS406/AB/R, para. 96.

4 The term "TBT measures" is used here to refer broadly to technical regulations, conformity assessment procedures and standards as defined in the WTO TBT Agreement.
} 
their conformity assessment procedures, except where, as duly explained upon request, such guides or recommendations or relevant parts are inappropriate for the Members concerned, for, inter alia, such reasons as: national security requirements; the prevention of deceptive practices; protection of human health or safety, animal or plant life or health, or the environment; fundamental climatic or other geographical factors; fundamental technological or infrastructural problems."

TBT WTO Agreement, emphasis added

2.3. Clearly, the obligation to use an international standard is strongly worded: Members shall use (in the case of technical regulations) or shall ensure the use of (in the case of conformity assessment procedures) relevant international standards, guides or recommendations. Because international standards provide a benchmark towards avoiding unnecessary barriers to trade (article 2.5), this obligation relates strongly to the concept of necessity. Avoiding unnecessary barriers to trade is at the core of the TBT Agreement. But equally important is the fact that, by definition, "necessary" barriers to trade exist and are allowed for - and this is an expression of governments' sovereign right to regulate.

\subsection{Striking the balance}

2.4. Thus, the Agreement provides flexibility which, in turn, gives policy space. This flexibility finds expression in a number of ways. To begin with, the word "relevant" itself (in articles 2.4 and 5.4) leaves room for a Member to argue that an international standard is not relevant in light of the particular policy situation, or due to the nature of the body setting the standard. This is markedly different from the WTO SPS Agreement which was modelled from the TBT Agreement and which explicitly names three international standardizing bodies. ${ }^{5}$ Second, Members have an obligation to use the relevant standard as a basis for regulation; this leaves room in terms of application, the standard does not necessarily have to be applied word-for-word. Third, a standard may be deemed to be an "ineffective or inappropriate means for the fulfilment of the legitimate objectives pursued" in technical regulations, or "inappropriate" for conformity assessment procedures (articles 2.4 and 5.4). For example, the level of protection that Members implicitly seek to achieve through their regulations may relieve them from using a given international standard (with a different level of protection). And fourth, in certain circumstances, developing country Members are not expected to use international standards which are not appropriate to their development, financial and trade needs (article 12.4 on special and differential treatment).

2.5. Where is the tension? While the flexibility that exists in the TBT Agreement is an essential part of the equilibrium, it is also at the root of many trade issues. For example, the fact that the Agreement in effect leaves each Member the choice of an international standard that it deems "relevant" in any given policy-making situation can be problematic: Members not only have different opinions on what a standard is (let alone an international one), but also tend to disagree on which bodies set standards that are "relevant" for the purposes of the WTO TBT Agreement. And who is to decide that a standard is not sufficiently effective or an inappropriate means of achieving a particular policy objective? Indeed, is this not a contradiction? If a standard is inefficient or inappropriate for one group of countries but not for another, is it still capable of being international? Of course, governments - being their own masters - have the right to take measures necessary to achieve their policy objectives at the levels they consider appropriate (Preamble of the TBT Agreement). But how, then, should international standards account for the fact that policy objectives may (legitimately) differ because, put simply, peoples are different with different preferences, social values, and appetites for risk? In other words, there may be cases where good faith efforts to address legitimate policy objectives (such as the protection of public health or safety and the environment) can lead to different levels of protection that cannot, by definition, find expression in one given international standard. Before proceeding to an exploration of how some of these issues come up in the WTO, we would make three qualifying points.

${ }^{5}$ CODEX Alimentarius Commission, the World Organization for Animal Health (The International Office of Epizootics? )(OIE) and the International Plant Protection Convention (IPPC). 


\subsection{Three qualifications}

2.6. First, in this paper we will focus on mandatory government intervention, i.e. on technical regulations and conformity assessment procedures. The topic of international standards is relevant to this because - as explained above - Members have a strong encouragement to use them as a basis for regulation.

2.7. The second qualification is related to the first. We do not cover issues related to the use of standards not enforced by virtue of government intervention. As set out above, the obligation to base measures on international standards (articles 2.4, 2.5 and 5.4) are only triggered when a government makes a decision to regulate. This "trigger" is important. It is important because an effective response to a policy problem or challenge does not necessarily imply regulation. ${ }^{6}$ Members are not obliged to regulate in the first place to address a particular policy objective. Quite to the contrary: on repeated occasions countries at the WTO have stressed the need to minimize the use of mandatory measures. ${ }^{7}$ In other words, this paper only considers the use of international standards once the decision has been taken to regulate - we are not concerned whether regulation was a good idea in the first place.

2.8. Third, although this paper relies heavily on data available on measures discussed at the WTO, it is not a statistical analysis. At best, it is an informed - albeit subjective - analysis of the debate on international standards at the WTO which could lead to a more in-depth review.

\section{WTO FORA: WHERE THE DISCUSSI ONS ARISE}

3.1. Discussions relevant to the use of international standards in regulation take place in many WTO forums: in Committee work (e.g., the TBT and SPS Committees), in the context of disputes, and in trade negotiations. We focus here on the TBT relevant aspects of these discussions.

\subsection{TBT Committee}

3.2. The work of the TBT Committee addresses international standards in the context of discussion of specific measures maintained by Members ("Specific Trade Concerns"), and in cross cutting work including decisions and recommendations taken by the Committee. We consider both in turn.

\subsubsection{Specific Trade Concerns}

\subsubsection{The nature of the discussion}

3.3. One of the core functions of the TBT Committee is acting as a forum to address trade issues - these are referred to as "Specific Trade Concerns" (hereafter STCs). These are concerns that one or several Members have with the design or implementation of another Member's measure. In most cases, STCs relate to measures that have been notified by Members. ${ }^{8}$ An analysis of the TBT Committee's records shows that about one third of all STCs raised in the TBT Committee are associated in one way or another with the subject of international standards. ${ }^{9}$ By "associated" we mean that international standards have been mentioned by a delegation in the discussion of a

${ }^{6}$ For more on the TBT Committee's work in this respect, see documents WTO (2008b), WTO (2008a) and WTO (2011d).

${ }^{7}$ First (1997) Triennial Review (WTO (1997), paras. 23 and 24(a)); Second (2000) Triennial Review (WTO (2000a), para. 38); Third (2003) Triennial Review (WTO (2003), para. 11); and the Fourth (2006) Triennial Review (WTO (2006), paras. 10 and 13). This type of assessment (to regulate or not) is increasingly done on the basis of a Regulatory Impact Assessment (RIA) in line with Good Regulatory Practices - and is at the heart of the Committee's work on Good Regulatory Practices (GRP).

${ }^{8}$ According to the transparency procedures of the TBT Agreement, draft measures which are not in accordance with international standards and which may have a significant effect on international trade should be notified through the Secretariat for review by the Membership.

${ }_{9}^{9}$ We have identified 129 STCS associated with international standards. We consider all STCs raised up to and including the November 2012 TBT Committee meeting. Records of discussions of the Committee are available on the WTO website under the symbol series: G/TBT/M/*. 
particular trade concern - either by reference to a specific body or organization, or through general reference to the existence (or non-existence) of some source of international guidance. ${ }^{10}$

3.4. While over forty different bodies or organizations are mentioned, a number of them recur frequently in discussion. The International Organization for Standardization (ISO) is mentioned in $30 \%$ of STCS associated with international standards; the FAO/WHO Codex Alimentarius Commission in 19\%; the International Electrotechnical Commission (IEC) in 12\%; the International Laboratory Accreditation Cooperation (ILAC) in 10\%; and, the United Nations Economic Cooperation for Europe (UNECE) in $10 \%$.

3.5. We note that the weight given in discussion to international standards differs from STC to STC: in some cases it is at the core of the issue, in others only a minor aspect. Moreover, the prominence of international standards in discussion of an STC may also vary according the meeting at which it is discussed. ${ }^{11}$

3.6. What is the nature of the discussions in relation to international standards? In order to give a flavour of the types of issues that have arisen, five typical concerns are described in the box below.

\section{Box 1: I nternational standards - illustrative examples}

Olive oil. In two related trade concerns on olive oil standards ${ }^{12}$, the United States and European Union challenged one another's measures for apparent deviations from international standards for grading. At dispute was the applicability of International Olive Council (IOC) olive oil grading standards (specifically for fatty acid composition) to an olive oil standard being set by the Codex Alimentarius Commission (CODEX). The United States argued that the European Union measure was following the IOC standards, which it did not consider to be an internationally recognized standard-setting body, since IOC standards reflected the interests of European and Mediterranean countries ("IOC grading standard reflected input exclusively from its members in European and Mediterranean countries"). Conversely, the European Union accused the United States measure of diverging from CODEX standards.

Lead in pottery. The European Union objected to a Mexican draft standard for glazed pottery, ceramics and porcelain ${ }^{13}$, which mandated more stringent lead and cadmium limits than those laid down in the relevant international ISO standards (ISO 6486-1/2). Specifically, the European Union was concerned that Mexican authorities would no longer accept test results accompanying EU ceramic tableware conducted in compliance with these ISO standards. Mexico explained that while its draft standard was partially based on ISO standards, it deviated in certain aspects due to a greater level of health protection required by Mexico, and due to the circumstances of Mexico as a developing country.

Mobile wireless. A Chinese measure was contested by the United States and European Union, which required that cell phones and smart phones sold in China be equipped to access the internet through both the international WiFi standard and China's WAPI standard. When asked to explain why it had not relied on the WiFi standard to meet its policy objective, China explained that it mandated dual standards to ensure safe operation of wireless networks and provide more reliable service and that the relevant IEC standard alone was not secure enough.

${ }^{10}$ Deciding which STCS have relevance to the topic of international standards is necessarily a matter of subjective judgment. We have used the following three decisive factors to classify STCS as "associated with international standards": (i) a standard or an international system for conformity assessment set by a multinational organization is explicitly mentioned in the discussion; (ii) there is a general reference to "international standards" or "guides and recommendations for conformity assessment" (even though no specific body is mentioned); or, (iii) reference is made to compliance with Articles 2.4 or 5.4. A full list of those bodies specifically mentioned in STCs "associated with international standards" is contained in Annex 1 , as well as those STCs that have been so associated (Annex 2).

${ }^{11}$ STCs may be raised at multiple meetings, either concurrently or non-concurrently - these are referred to previously raised STCs. Of the 364 STCs raised to date, $38 \%$ have been raised only once, while the remaining $62 \%$ have been raised at multiple meetings.

${ }_{12}$ United States - Olive Oil (G/TBT/N/USA/395); EC - Marketing Standards for Olive Oil (G/TBT/N/EEC/226).

${ }^{13}$ Mexico - Standard for Glazed Pottery Ware, Glazed Ceramic Ware and Porcelain Ware. 
Frozen poultry. Brazil and Australia challenged a European Union measure which would prohibit previously frozen poultry meat from being used in "fresh" poultry meat preparations. ${ }^{14}$ Amongst other arguments, they claimed the measure was not in line with definitions of fresh poultry meat contained in international standards, such as those of the World Organization for Animal Health (OIE). Although the European Union did not respond to claims about international standards, it is notable that the EU measure appears to be in line with definitions contained in a different international standard: a Codex standard, the Code of Hygienic Practice for Meat - "Definitions".

Lithium batteries. A number of Members, including China, Japan, Korea and the European Union raised concerns with a US regulation for the transportation of lithium batteries by air. ${ }^{15}$ They accused the United States of setting more restrictive transportation packaging requirements, which went beyond those laid out in international standards set by the International Civil Aviation Organization (ICAO). The United States did not debate that they were not following ICAO standards; indeed, they argued that their measure was designed to achieve a higher level of protection against the specific risk of lithium batteries catching fire when transported by air. The United States argued that the ICAO standard setting process was procedurally flawed, since it did not take account of all relevant scientific information, and thus lead to a standard that was deficient from a technical perspective. Also, it was pointed out that ICAO was not following the TBT Committee Decision on principles for developing international standards (see below), in particular on consensus (decisions in the ICAO are taken by voting).

3.7. The box above provides five illustrative examples, but they understate the complexity of the issues: each of the 129 STCs analysed presents a unique story - and link - to international standards. In an effort to categorize the discussions, we have identified three broad narratives as follows:

a. Challenge. The vast majority (around 90\%) relate to some form of "challenge" on international standards (from one Member to another). The tone of the discussions may range from a polite request for clarification about the use or non-use of international standards in a measure, to a direct accusation that a Member is not following a specific (and in their view relevant) international standard and therefore violating a WTO discipline. We analyse this narrative in more detail below.

b. Defence. In these cases, Members emphasize that they are following a relevant international standard (as a basis for a technical regulation or conformity assessment procedure) as a way of deflecting other challenges under the TBT Agreement (e.g., that a measure is unnecessarily trade restrictive). This is a way of operationalizing the "rebuttable presumption" contained in Article 2.5 of the TBT Agreement (the "safe haven" effect). ${ }^{16}$

c. No (obvious) standard. The lack of an obvious "candidate" international standard also creates tension. There have been instances where Members mention apparent gaps in international standards as a reason for trade problems. For example, the lack of internationally agreed definitions has come up on a number of occasions, such as with respect to "liquor". ${ }^{17}$ There may also be cases where guidance is emerging (perhaps in a

${ }^{14}$ Poultry meat preparations refers to meat which has been processed or to which seasonings and additives are added, but still retains the characteristics of raw meat.

${ }^{15}$ United States - Hazardous Materials: Transportation of Lithium Batteries (G/TBT/N/USA/518)

16 The second sentence of Article 2.5 states: "Whenever a technical regulation is prepared, adopted or applied for one of the legitimate objectives explicitly mentioned in paragraph 2, and is in accordance with relevant international standards, it shall be rebuttably presumed not to create an unnecessary obstacle to international trade" (emphasis added).

${ }^{17}$ In one example the United States expressed concern with South Africa's Liquor Products Act of 1989, setting out quality and identity standards for spirits to be marketed in South Africa (South Africa - Liquor Products Act of 1989). South Africa responded by noting that, to the best of their knowledge, there was no specific international standard related to liqueur, and therefore, regulation of such products was subject to national regulations. South Africa also underscored that existing guidelines by the International Organization for Wine and Vine (OIV), and the Liquor Products Act (1989) did not necessarily apply to the current situation. In another example from 2000, the EU explained in the context of a GMO labelling measure that there was an absence of international standards in the area owing to an absence of international methodologies to detect DNA or protein (European Communities - Compulsory Indication of the Labelling of Certain Foodstuffs Produced from GMOs). 
regional or sectoral context) but has not yet crystalized as a coherent initiative to develop an international source of guidance. ${ }^{18}$

3.8. Below we focus on the most frequently observed narrative: "challenge". We conducted a further analysis to identify a rough typology of the the responses of Members to challenges about international standards in the STC discussion.

Figure 1: Response to Challenges

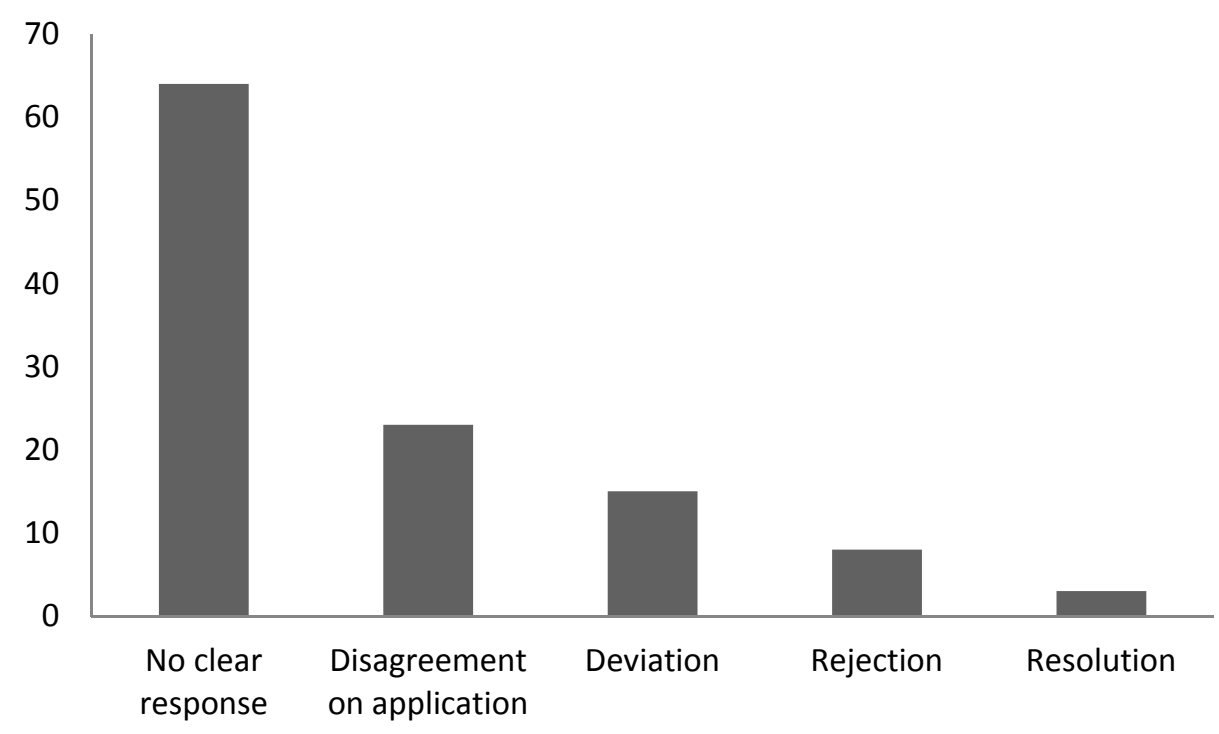

Table 1: Response to Challenges

\begin{tabular}{|c|l|}
\hline $\begin{array}{c}\text { Response } \\
\text { response }\end{array}$ & $\begin{array}{l}\text { In the majority of cases, the challenged Member does not provide a clear } \\
\text { response about the reasons why a particular international standard is not being } \\
\text { used. }\end{array}$ \\
\hline $\begin{array}{c}\text { Disagreement } \\
\text { on application } \\
\text { (use of) }\end{array}$ & $\begin{array}{l}\text { The most complex exchanges relate to disagreement on the application of a } \\
\text { particular international standard. In the predominate mode, after being taken to } \\
\text { task for not following a specific international standard, Members claim that they } \\
\text { are, in fact, following the international standard in question. This sort of exchange } \\
\text { would appear to reflect variations in how Members use international standards as } \\
\text { a basis for national regulation (see paragraph 3.26 below). }\end{array}$ \\
\hline Deviation & $\begin{array}{l}\text { This response involves a Member being explicit about a deviation made from the } \\
\text { international standard in question (in order to meet their legitimate objectives). } \\
\text { Under this sort of response, Members specify that the measure and the } \\
\text { international standard are otherwise compatible. Applying the terms developed by }\end{array}$ \\
\hline
\end{tabular}

${ }^{18}$ For instance, a number of trade concerns raised in the TBT Committee relate to nanotechnology: Korea - Proposed Cosmetics Labelling and Advertisement Guidelines (G/TBT/N/KOR/308); KFDA draft Guidelines for Management of Nanomaterials in Cosmetics; European Union - Directive 2002/95/EC on the Restriction of the Use of certain Hazardous Substances in Electrical and Electronic Equipment (RoHS) and Directive 2002/96/EC on Waste Electrical and Electronic Equipment (WEEE) (G/TBT/N/EEC/247 and G/TBT/Notif.00/310, Corr.1; European Union - Regulation on the Registration, Evaluation and Authorization of Chemicals (REACH) (G/TBT/N/EEC/52 and Adds.1-6; Add.3/Rev.1; G/TBT/N/EEC/295 and 297). At the Committee meeting of J une 2011, the United States drew attention to a memo on "Policy Principles for the U.S. Decision-Making Concerning Regulation and Oversight of Applications of Nanotechnology and Nanomaterials", US Federal agencies were encouraged, inter alia, to coordinate and undertake collaborative research across the international community and clearly communicate the regulatory approaches and understanding of the United States to other nations. Other areas include work on electrical vehicles, solar technology, and energy efficiency (US Executive Office of the President (Offices of Management and Budget, Sciences and Technology and the USTR), dated 9 June 2011, distributed to the TBT Committee in March 2011). 


\begin{tabular}{|c|l|}
\hline Rejection & $\begin{array}{l}\text { ISO/IEC, this would imply use of a "modified" international standard in the } \\
\text { measure at issue. }\end{array}$ \\
\hline $\begin{array}{c}\text { In these cases, a challenged Member rejects the international standard put } \\
\text { forward by concerned Members as the appropriate basis for regulation. Often the } \\
\text { rejection is tied to the body or organization that is setting the standard and may } \\
\text { be tied to perceived flaws in the process through which the standard was set. For } \\
\text { example, the challenged Member was not a member of that body or scheme (or } \\
\text { could otherwise not participate) and thus rejects the standards. Applying the } \\
\text { terms developed by ISO/IEC, this would imply that the measure and international } \\
\text { standard were "not equivalent".20 }\end{array}$ \\
\hline Resolution & $\begin{array}{l}\text { In a small number of cases, the responses suggest some degree of mutual } \\
\text { understanding has been achieved. The resolution will often be reported some } \\
\text { meetings after the initial concern was raised - usually with the challenged } \\
\text { Member having brought its measure closer in line with international standard. }\end{array}$ \\
\hline
\end{tabular}

3.9. We reiterate that the classification of the responses in Table 1 (and Figure 1) are illustrative in nature. No case or STC is the same: like disputes they tend to be complex and technical - and even a rich discussion in the Committee is not enough to fully describe either the measure at issue or the arguments aired. Therefore the classification of "responses" that we offer needs to be seen as caricatures of reality, sharpened for illustrative purposes. We nevertheless believe that they do offer an insight into nature of the discussion on international standards in the TBT Committee.

\subsubsection{The value of the discussion}

3.10. One tangible result of all three narratives as described above is increased transparency. ${ }^{22}$ The debate raises awareness about the use (or on-use) of international standards (which is particularly useful for regulators); and about potential gaps in international standard setting work (which is particularly useful for standard-setting bodies). Discussions offer an opportunity for peer review that helps align Members' national practices; put differently, they are a conduit for regulatory cooperation between Members that promotes convergence, including with respect to the use of international standards.

3.11. Transparency thus contributes to operationalize the Agreement in two key ways. First, the fact that the measures under discussions are generally in draft form, most of which (76\%) have been notified to the Committee, means that there is still time for the measure to be amended prior to entry into force. This window gives an opportunity for Members to align regulations and move towards a common benchmark. Second, the framework of repeated interactions at set times (the Committee meets three times per year) gives a backdrop against which measures are tracked, updates are provided and - in some cases - resolutions found. ${ }^{23}$

3.12. An altogether different question is how effective the mechanism is in "settling" trade concerns. We do not have an obvious answer. There is no procedure in place to "report" on resolutions of STCs in TBT Committee - and those that we included in the right-most bar of Figure 1 are those that can be inferred from the discussion - but these are exceptions, and there is no official confirmation of such trade concerns having been resolved. In most cases challenges are not responded to. We could, of course, suggest that many of the concerns are resolved to some degree, even if not reported as such. ${ }^{24}$ But that is not our main point. We argue here that it is

19 ISO/IEC Guide 21-1:2005(E) Regional or national adoption of International Standards and other International Deliverables - Part 1: Adoption of International Standards, page 4. See: http://www.iso.org/iso/iso_iec_guide_21-1_2005.pdf

${ }^{20}$ I bid, page 5.

${ }^{21}$ For example, after being challenged for not accepted test carried out according to international guides and recommendations, Brazil later indicated that these results would be accepted (Brazil - Toys).

${ }^{22}$ Wolfe (2013).

${ }^{23}$ WTO (2006), paragraph 65.

${ }^{24}$ The SPS Committee has put in place a procedure whereby Members are encouraged to report on "resolutions". Under this procedure, since 1995 and until the end of 2012, some 96 of STCs of 344 (28\%) 
the forum itself that is useful: as a means for multilateral review of draft measures, and as a means of raising awareness (e.g. on gaps in international standards, use or non-use of international standards by governments). This information is also an important feedback into the governance of international standard setting. Because the Committee is used for a discussion of draft measures, it can contribute to pre-empting larger problems down the road.

\subsubsection{Decisions and Recommendations}

3.13. Aside from the discussion of STCS, the topic of international standards figures prominently in the generic (horizontal) discussions that take place in the TBT Committee; this discussion is essentially about furthering implementation of the Agreement through decisions and recommendations. ${ }^{25}$ On a three-year cycle, the Committee reviews the operation of the Agreement - on the basis of Members' submissions - and elaborates action points for improvement, contained in the report of the review (the Triennial Review). Arguably, the most significant decision taken by the TBT Committee to date relates to international standards: the 2000 Decision on Principles for the Development of International Standards, Guides and Recommendations with Relation to Articles 2, 5 and Annex 3 of the TBT Agreement (from the $2^{\text {nd }}$ Triennial Review).

3.14. This Decision (referred to hereafter as the "Six Principles") sets out six principles that are considered important for the process of international standards development; these are summarized below: ${ }^{26}$

a. Transparency: All essential information regarding current work programmes, as well as on proposals for standards, guides and recommendations under consideration and on the final results should be made easily accessible to at least all interested parties in the territories of at least all WTO Members. Procedures should be established so that adequate time and opportunities are provided for written comments.

b. Openness: Membership of an international standardizing body should be open on a nondiscriminatory basis to relevant bodies of at least all WTO Members. This would include openness, without discrimination, with respect to the participation at the policy development level and at every stage of standards development. Especially developing country members, with an interest in a specific standardization activity should be provided with meaningful opportunities to participate at all stages of standard development.

C. I mpartiality and consensus: All relevant bodies of WTO Members should be provided with meaningful opportunities to contribute to the elaboration of an international standard so that the standard development process will not give privilege to, or favour the interests of, a particular supplier/s, country/ies or region/s. Consensus procedures should be established that seek to take into account the views of all parties concerned, and to reconcile any conflicting arguments.

d. Effectiveness and relevance: In order to serve the interests of the WTO membership in facilitating international trade and preventing unnecessary trade barriers, international standards need to be relevant and effectively respond to regulatory and market needs, as well as scientific and technological developments in various countries. They should not distort the global market, have adverse effects on fair competition, or stifle innovation and technological development. In addition, they should not give preference to the characteristics or requirements of specific countries or regions when different needs or interests exist in other countries or regions. Whenever possible, international standards should be performance-based rather than based on design or descriptive characteristics.

e. Coherence: In order to avoid the development of conflicting international standards, it is important that international standardizing bodies avoid duplication of, or overlap with,

have been reported as "resolved". It is likely that at least some TBT STCs are similarly resolved although they have not officially been reported as such. See Wijkström and McDaniels (2012) for more information.

${ }^{25}$ WTO (2011c).

${ }^{26}$ The full text of this Decision is contained in Annex B of WTO (2011c). 
the work of other international standardizing bodies. In this respect, cooperation and coordination with other relevant international bodies is essential.

f. Development Dimension: Constraints on developing countries, in particular, to effectively participate in standards development, should be taken into consideration in the standards development process. Tangible ways of facilitating developing countries' participation in international standards development should be sought. The impartiality and openness of any international standardization process requires that developing countries are not excluded de facto from the process. With respect to improving participation by developing countries, it may be appropriate to use technical assistance, in line with Article 11 of the TBT Agreement. Provisions for capacity building and technical assistance within international standardizing bodies are important in this context.

3.15. At the two latest triennial reviews (in 2009 and in 2012), Members stressed the importance of ensuring full application of these six principles. ${ }^{27}$ Over recent years, these principles - which have gone relatively unnoticed for a decade - have figured in discussions both in the context of the negotiations (see Section $C$, below) as well as in the disputes (see Section B, below).

3.16. It is likely that following the recommendations adopted at the end of 2012, Members will now engage in a more detailed discussion on the extent to which: (i) bodies involved in international standard-setting are putting the Six Principles into practice; and (ii) how Members themselves are promoting the use of these principles in bodies that they consider to set relevant international standards for the purposes of the TBT Agreement.

\subsection{Disputes}

3.17. Four disputes have been adjudicated at the WTO which are, to varying degrees, relevant to the topic of international standards and the TBT Agreement (Table 1). We consider the following three aspects: (i) whether a relevant international standard exists; (ii) whether (and how) it has been used as a basis for regulation; and (iii) whether it is an effective and/or appropriate means for the fulfilment of the objective of the regulation. ${ }^{28}$

Table 2: Selected TBT Disputes ${ }^{29}$

\begin{tabular}{|c|c|c|c|}
\hline \# & Title & $\begin{array}{l}\text { Complainant and date of } \\
\text { Consultation Request } \\
\text { (in reverse chronological order) }\end{array}$ & Dispute \\
\hline 1 & $\begin{array}{l}\text { US - Clove Cigarettes } \\
\text { United States-Measures Affecting the } \\
\text { Production and Sale of Clove Cigarettes } \\
\end{array}$ & Indonesia, 7 April 2010 & DS406 \\
\hline 2 & $\begin{array}{l}\text { US - COOL } \\
\text { United States-Certain Country of Origin } \\
\text { Labelling (Cool) Requirements }\end{array}$ & $\begin{array}{l}\text { Mexico, } 17 \text { December } 2008 \\
\text { Canada, } 1 \text { December } 2008\end{array}$ & $\begin{array}{l}\text { DS386 } \\
\text { DS384 }\end{array}$ \\
\hline 3 & $\begin{array}{l}\text { US - Tuna I I } \\
\text { United States-Measures Concerning the } \\
\text { I mportation, Marketing and Sale of Tuna and } \\
\text { Tuna Products }{ }^{32}\end{array}$ & Mexico, 24 October 2008 & DS381 \\
\hline 4 & $\begin{array}{l}\text { EC - Sardines } \\
\text { European Communities }- \text { Trade Description of } \\
\text { Sardines (Complainant: Peru) }\end{array}$ & Peru, 20 March 2001 & DS231 \\
\hline
\end{tabular}

${ }^{27}$ WTO (2009a), para. 25(c) and WTO (2012a), para. 8

${ }^{28}$ This order of analysis was used in the US - Tuna II (Panel Report, §7.627).

${ }^{29}$ Disputes where claims related to the TBT Agreement were treated by Panels and Appellate Body as decisive criterion and not claims per se. Aside from the above, claims under the TBT Agreement have been made in 39 other requests for consultations since 1995. For more detail on these claims, see:

http://www.wto.org/english/tratop_e/dispu_e/dispu_agreements_index_e.htm?id=A22\#selected_agree $\underline{\text { ment }}$

${ }^{30}$ For more detail, see: http://www.wto.org/english/tratop_e/dispu_e/cases_e/ds406_e.htm.

${ }^{31}$ For more detail, see: http://www.wto.org/english/tratope/dispu e/cases e/ds384 e.htm (complaint by Canada) and http://www.wto.org/english/tratop_e/dispu_e/cases_e/ds3384_e.htm (complaint by Mexico).

${ }^{32}$ For more detail, see: http://www.wto.org/english/tratop_e/dispu_e/cases_e/ds381_e.htm. 


\subsubsection{Existence of a relevant international standard}

3.18. The TBT Agreement in various articles (Articles 2, 5, 6 and Annex 3) refers to the concept of a "relevant international standard" without defining what this concept means. This issue was central to the first TBT dispute adjudicated at the WTO, EC - Sardines. ${ }^{34}$ In this case, Peru brought a challenge under Article 2.4 against an EURegulation controlling labelling and marketing of preserved sardines. The EC Regulation mandated that only those products prepared from a specific species of sardine, Sardina pichardus (European sardines), could be marketed and labelled as preserved sardines, while products prepared from other species of sardine, such as Sardinops sagax (Peruvian sardines), could not. The case turned on the relevance of an international standard for canned sardines and sardine type products (Codex Stan 94) set by the Codex Alimentarius Commission (Codex).

3.19. Two findings from EC - Sardines are worth highlighting in this context: one on the subject of relevance and the other on the term consensus - both in relation to the international standard. On the former, the Panel referred to the ordinary meaning of the term "relevant" as "bearing upon or relating to the matter in hand; pertinent". ${ }^{35}$ The Codex standard at issue set forth specific labelling provisions for preserved sardines and sardine-type products prepared from 21 species, including the two in dispute. Since the Codex standard and the EC Regulation both applied to both types of sardines in dispute (by exclusion, and legal consequences thereof, in the case of the EU Regulation), the Appellate Body found that the Codex standard bears upon, relates to, or is pertinent to the EU Regulation. ${ }^{36}$ Therefore, the Codex standard was a "relevant international standard" in this case. ${ }^{37}$

3.20. Turning to the latter, it should be noted that no party disputed that Codex was an international standardization body ${ }^{38}$, rather the focus was the process by which the standard was approved. The Appellate Body found that standards not adopted by consensus by a "recognized body" of the international standardization community fell within the definition of a "standard" in Annex 1.2, and thus were relevant for the purposes of Article 2.4 of the Agreement. ${ }^{39}$

3.21. The topic of international standards was also addressed in US - Tuna II, albeit in a different manner. ${ }^{40}$ This dispute arose out of a challenge brought by Mexico against certain legal instruments of the United States (including the US Dolphin Protection Consumer Information Act) which establish the conditions for the use of a "dolphin-safe" label on tuna products. In this case, the analysis in respect of the existence of a relevant international standard hinged, to a large extent, on the characteristics of the body that set the standard in terms of openness and recognition. In assessing the meaning of the term international standard for the purposes of the TBT Agreement, the Appellate Body established that a prospective international standard must be approved by an "international standardizing body", which it defined (through interpretation of definitions contained in Annex 1, and in the ISO/IEC Guide 2: 1991) as "a body that has recognized activities in standardization and whose membership is open to the relevant bodies of at least all Members". ${ }^{41}$

3.22. The Appellate Body considered whether the "dolphin-safe" definition and certification developed within the framework of the AIDCP ${ }^{42}$ constituted a "relevant international standard" in

${ }^{33}$ For more detail, see: http://www.wto.org/english/tratop_e/dispu_e/cases_e/ds231_e.htm.

${ }^{34}$ European Communities - Trade Description of Sardines (Panel and Appellate Body Reports (WT/DS231/R and WT/DS/231/AB/R).

${ }^{35} \mathrm{EC}$ - Sardines Panel Report, para. 7.68, quoting Webster's New World Dictionary (William Collins \& World Publishing Co., Inc. 1976), p. 1199.

${ }^{36}$ EC - Sardines ABR, paras. $231-232$

${ }^{37} \mathrm{EC}$ - Sardines ABR, paras. 233.

38 The European Commission did not contest that the Codex Alimentarius Commission was an international standardizing body, and that it is a "recognized body" for purposes of the definition of a "standard" in Annex 1.2. EC - Sardines, WT/DS/231/AB/R, para. 221.

${ }^{39}$ EC - Sardines ABR, para.s 219 - 227.

40 United States - Measures Concerning the Importation, Marketing and Sale of Tuna and Tuna Products, WT/DS381/R.

${ }^{41}$ WT/DS381/AB/R, para 359.

${ }^{42}$ This is the dolphin-safe standard established by the Agreement on the International Dolphin Conservation Programme (AIDCP). The AIDCP establishes dolphin mortality limits binding upon all tuna fleets 
this case, by assessing AIDCP against its definition of "international standardizing body". Focusing on the requirement for openness to the relevant bodies of at least all Members, it disqualified the AIDCP as an "international standardizing body" on the basis that new parties can accede only by invitation (and parties to the AIDCP had to take the decision to issue an invitation by consensus) thus the Appellate Body concluded the AIDCP standard was not a "relevant international standard" for the purposes of Article 2.4. It further elaborated on openness, and explained that an open body must not apply restrictions on membership (by WTO Members) ${ }^{43}$, that accession to the body should be practically automatic ${ }^{44}$, and that it must be open at all stages of standards development, not just at one point in the process or one point in time (as drawn from the Committee Decision, see below). ${ }^{45}$ The Appellate Body did not pronounce on whether the AIDCP had recognized activities in standardization (the other half of its definition of an "international standardizing body"), but did provide a number of signposts on what this requirement might entail.

3.23. By way of context, the Appellate Body cited the regular definition of "recognize", and noted that this concept had both factual and normative aspects. ${ }^{46}$ In no particular order, the Appellate Body clarifies that an important aspect of recognition is that the existence, legality and validity of a body's standards be acknowledged by WTO Members and their national standardizing bodies ${ }^{47}$, for example through reference in national standards, technical regulations or conformity assessment procedures. However, the Appellate Body qualifies this point, stating that this does not mean that only those bodies whose standards are widely used can have recognized activities in standardization for the purposes of the TBT Agreement. ${ }^{48}$ In other words, bodies that develop standards that are not widely used could still be seen as having recognized activities in standardization. It is further pointed out that the bodies that have developed only one standard could still be considered as having recognized activities in standardization. ${ }^{49}$ Moreover, standardization need not be the principal function of the body for it to be considered as having recognized activities in standardization. ${ }^{50}$ However, Members needed to at least be aware, or have reason to expect, that the international body in question was engaged in standardization activities. ${ }^{51}$ In passing, the Appellate Body also inferred that the larger the number of countries participating in the development of a standard, the more likely it can be said that the respective body's activities in standardization are "recognized". ${ }^{2}$ Finally, and of particular interest to this paper, the Appellate Body stated that evidence that a body followed the six principles of the Committee Decision (e.g. through transparency, and normatively) in development of a standard was part of the determination of whether the body's activities in standardization were recognized. ${ }^{53}$

3.24. Indeed, the Committee Decision held weight in US - Tuna II; the Appellate Body considered it as a "subsequent agreement" within the meaning of Article 31(3)(a) of the Vienna Convention thus informing the interpretation and application of terms in the TBT Agreement itself. ${ }^{54}$ This conclusion was based on the fact that the Committee Decision sets out several principles that WTO Members have decided "should be observed" when international standards, guides, and recommendations are elaborated to ensure transparency, openness, impartiality and consensus, effectiveness and relevance, coherence, and to address the concerns of developing countries. ${ }^{55}$ In this dispute, the Appellate Body used the Committee Decision to help interpret the concepts of openness and recognized activities in standardization, but did not preclude relying on other aspects of it in future cases to the extent it "'bears specifically' on the interpretation and application of the respective term or provision". ${ }^{56}$

fishing in the ETP, and prescribes the use of specific fishing techniques and fishing gear to reduce dolphin bycatch.

${ }^{43}$ WT/DS381/AB/R, para. 364

${ }^{44}$ I bid., para. 386

${ }^{45}$ Ibid., para. 374

${ }^{46}$ I bid., para. 361.

${ }^{47}$ I bid, paras. 363, 392.

${ }^{48}$ I bid. , para. 392.

${ }^{49}$ I bid. , para.s 360, 394.

${ }^{50}$ I bid. , para. 362.

${ }^{51}$ I bid. , para. 362.

${ }^{52} \mathrm{l}$ bid. , para. 390.

${ }^{53}$ Ibid. , para. 394.

${ }^{54}$ Ibid. , para. 372.

${ }^{55}$ WT/DS381/AB/R, para. 370.

${ }^{5}$ Ibid. , para. 372. 
3.25. The US - Clove Cigarettes ${ }^{57}$ case related to a US measure banning the production and sale of cigarettes with flavours other than tobacco or menthol. While no claim was made under Article 2.4 about the existence of a relevant international standard ${ }^{58}$, the Panel stated that it was aware of important international efforts to curb smoking within the context of the WHO Framework Convention on Tobacco Control (the "FCTC"), which was part of the factual context. ${ }^{59}$

\subsubsection{Use of (as a Basis)}

3.26. We recall first the discipline from above: in the case that a relevant international standard exists, the TBT Agreement contains a strong encouragement that Members use relevant international standards (guides or recommendations for conformity assessment procedures) as a basis for their technical regulations (or conformity assessment procedures). Also, the TBT Agreement provides a "safe haven" whereby technical regulations are presumed not to create unnecessary obstacles to international trade if they are in accordance with a relevant international standard. Thus the term "use as a basis" leaves some flexibility in respect of how the chosen international standard is actually applied.

3.27. The meaning of this term ("use as a basis") was analysed by the Appellate Body in EC Sardines. Noting that its approach in EC - Hormones ${ }^{60}$ was relevant for the interpretation of Article 2.4 of the TBT Agreement, the Appellate Body stated, in EC - Sardines, that an international standard is used "as a basis for" a technical regulation when it is used as the principal constituent or fundamental principle for the purpose of enacting the technical regulation. There had to be a "very strong and very close relationship" between the measure and the standard in order to be able to say that one is the basis for the other; and, at a minimum, there could not be a contradiction. ${ }^{61}$

3.28. In practice, this would appear to leave Members considerable room for manoeuvre. For example, sometimes the legal instrument (regulation, statue, decree) may reproduce the wording of the standard itself, or part of it. In other cases, the standard is "incorporated" by simple reference, or as a source of guidance, but the wording is not actually reproduced. ${ }^{62}$

\subsubsection{Effectiveness and Appropriateness}

3.29. There is an explicit exception in the text of the TBT Agreement that may relieve Members from the obligation of using a relevant international standard: Members are not required to use an international standard as a basis for the regulation (whether a technical regulation or conformity assessment procedure ${ }^{63}$ ) if it would not be appropriate or effective for achieving the desired level of protection in respect of the policy objective.

3.30. On this specific aspect the jurisprudence is brief. The Appellate Body has stated that an ineffective means is a means which does not have the function, or the result, of accomplishing the legitimate objective pursued. An inappropriate means is a means which is not especially suitable

${ }^{57}$ United States - Measures Affecting the Production and Sale of Clove Cigarettes, WT/DS406/R.

${ }^{58}$ It is notable that the Panel explicitly referred to the fact that Indonesia had made no claim under Article 2.4, even though at one point Indonesia appeared to argue that the United States should have used a "relevant" international standard as a basis for its technical regulation (ASTM E679 - 04 "Standard Practice for Determination of Odor and Taste Thresholds By a Forced-Choice Ascending Concentration Series Method of Limits"). (WT/DS406/R paragraph 7.496).

${ }^{59}$ Several parts of the Panel Report refer to the WHO, see WT/DS406/R paragraphs: 2.29 - 2.32; 7.1; 7.5; 7.218-7.220; 7.229-7.231; 7.413-7.416; and, 7.427. The Appellate Body "recognize[d] the importance of Members' efforts in the World Health Organization on tobacco control" (WT/DS406/AB/R, dated 4 April 2012, para. 235).

${ }^{60}$ Appellate Body Report, WT/DS26/AB/R, WT/DS48/AB/R, adopted 13 February 1998.

${ }^{61}$ For more detail, see Appellate Body Report, WT/DS231/AB/R (hereafter "EC-Sardines"), 26 September 2002, paras. 243 - 248, 257.

${ }^{62}$ For more information on this, see the material pertaining to the WTO TBT Workshop on Good Regulatory Practice, 18-19 March 2008 (Presentation by Shortall in particular).

${ }^{63}$ In the case of conformity assessment procedures, the text of the TBT Agreement (in Article 5.4) on the exception refers to situations where the relevant "guides or recommendations" are inappropriate for the Members concerned (i.e., there is no reference to effectiveness). 
for the fulfilment of the legitimate objective pursued, due to the nature of the standard. ${ }^{64}$ It is up to the complainant to make a prima facie case that the international standard is effective and appropriate for the achievement of the legitimate objectives sought by the measure. ${ }^{65}$

3.31. In US - COOL, the Panel found (not appealed) that the standard at issue (a Codex standard which it assumed was relevant) did not have the function or capacity of accomplishing the legitimate objective sought by the measure - it was thus neither effective nor appropriate. ${ }^{66}$ This was because the Codex standard in question confers origin according to the concept of substantial transformation (thus, an animal's origin is determined exclusively by where it was slaughtered), and therefore could not achieve the objective of providing information to consumers about the countries in which an animal was born, raised and slaughtered. ${ }^{67}$ Similarly, in US - Tuna II, the Panel was of the view that while the relevant international standard did contribute to the objective sought by the US, it failed to do so in some respects - and the complaining party (Mexico) had thus failed to show that it was an effective and appropriate means to fulfil the US objectives. ${ }^{68} \mathrm{In}$ US - Tuna II the issue of effectiveness was not addressed on appeal as the Appellate Body found that the Panel had erred in finding that the standard was "relevant" to begin with. ${ }^{69}$

\subsubsection{Summary (Annex III)}

3.32. This discussion has focused in on Panel and/or Appellate Body rulings that are particularly relevant to Article 2.4 of the TBT Agreement. By way of summary, Annex III lists some of the key concepts (e.g., "consensus", "openness", "recognized activity") along-side Panel and/or Appellate Body pronouncements. ${ }^{70}$

\subsection{Negotiations}

3.33. Finding ways to promote the use of international standards is also the subject of negotiations under the Doha Development Agenda, particularly under the Non-Agricultural Market Access discussions of non-tariff barriers (NAMA NTBs). The 2001 Doha Ministerial Declaration instructs WTO Members to negotiate the reduction of both tariffs and non-tariff barriers (NTBs) in international trade of industrial products. ${ }^{71}$ Many proposals have been made to date and several are relevant to the implementation of the TBT Agreement and/or the work of the TBT Committee. ${ }^{72}$ Of most interest to this paper, the reference to relevant international standards contained in the TBT Agreement was much debated (Articles 2.4 and 5.4)..$^{73}$ As has been explained above, the TBT Agreement does not explicitly name any international standardizing body as "relevant" body for the purposes of implementing the Agreement's provisions. Indeed, Members have the choice when regulating to decide which international standard (if any) may be relevant in a given situation.

3.34. In the negotiations, one group of Members argue that relevant international standardizing bodies should be explicitly named. Since the goal of the TBT Agreement itself is one of promoting harmonization, this very objective, it is argued, will be impeded if multiple standardsetting organizations co-exist creating duplicative and possibly contradictory requirements. In a context where regulators face a qualified obligation to base their measure on international

${ }^{64}$ Both the recent US-COOL and US - Tuna II panels referred to AB findings in EC-Sardines with respect to this issue. See, in particular: Panel Report, US-Cool. para. 7.730; Panel Report, US - Tuna II. paras. 7.721; Panel Report, EC - Sardines, para. 7.116; WT/DS231/AB/R, paragraphs 274-275 and 285-290.

${ }^{65}$ WT/DS231/AB/R, para. 287.

${ }^{66}$ Panel Report, US-Cool. para. 7.734 - 7.735. The AB refers in ABR US-Cool para. 190.

67 Panel Report, US-Cool. para. 7.734.

${ }^{68}$ Panel Report, US - Tuna II, 7.738 - 7.740.

${ }^{69}$ ABR, US - Tuna II, para. 400.

70 WTO (2013) provides more detail of TBT case law.

71 The Doha Ministerial Declaration (November 2001) includes a mandate to negotiations aimed to "reduce or as appropriate eliminate tariffs, including the reduction or elimination of tariff peaks, high tariffs, and tariff escalation, as well as non-tariff barriers, in particular on products of export interest to developing countries. ..." (Para 16 on Market access for non-agricultural products, emphasis added).

72 During a first stage of the negotiations, beginning in 2002, WTO members undertook a notification exercise aimed at identifying difficulties encountered by economic operators with respect to non-tariff barriers. A number of dedicated sessions aimed at examining the notifications were held in $2004-2005$. After that, the negotiations moved into a phase of consideration of specific text-based negotiating proposals.

73 More information on the NAMA negotiations is available at: http://www.wto.org/english/tratop e/markacc e/markacc negoti e.htm . 
standards, competition between standard-setting bodies will lead to fragmentation of markets, unnecessary compliance costs and even capture of regulators by protectionist interests. These Members argue that we must strive for the contrary: close co-operation, greater inclusiveness and sharing of governance at the international level. Focusing the development of standards used for regulatory purposes in a few international bodies will incentivize a broad participation by stakeholders, in particular industry, thus ensuring market relevance and reflecting technological developments. ${ }^{74}$ This would, in their view, facilitate regulatory convergence.

3.35. Another group of Members argues the exact opposite: international standardizing bodies should not be named because whether a standard is relevant, effective and appropriate in fulfilling a Member's particular regulatory or market need depends on the standard itself, not on the body that developed the standard. They argue that Article 2.4 of the TBT Agreement links the relevance of a "standard" to the objective pursued; the term "relevant" is not linked to the body. Furthermore, they suggest that by designating a particular body as a "relevant international standardizing body" WTO Members would essentially be endorsing all standards that such bodies produce without reviewing their content, even in cases where the standard might not reflect the interests of all Members, or, disproportionately reflects those of only a few. ${ }^{75}$ It is also argued that a limited number of named bodies cannot produce the breadth and diversity of standards needed to fulfil all of the regulatory and market needs that are the purview of the TBT Agreement. ${ }^{76}$ Instead, it is the diversity of bodies that will promote innovation and help ensure that standards are of high quality and respond to regulatory and market needs. Greater harmonization will result from increased use of such standards. ${ }^{77}$

\section{LOOKI NG AHEAD: I MPROVI NG GOVERNANCE TO PROMOTE REGULATORY ALI GNMENT}

\subsection{Challenges for Governance of I nternational Standard Setting}

4.1. Governance of international standard setting is of central importance to the trade community because of the fundamental role that international standards are given in the TBT Agreement. As mentioned at the outset, the TBT Agreement encourages the development of international standards, stresses their use by WTO members as a basis for regulation, and holds them up as a principal basis for regulatory alignment to facilitate international trade. The logic of reducing or avoiding unnecessary barriers hinges on the use of relevant international standards as a benchmark for regulation. The better the international standard setting system works, the more useful the resultant standards are in addressing unnecessary trade barriers and promoting alignment of regulation.

4.2. Governance arrangements for international standard setting are complex, involving a range of actors (e.g. governments, national standardizing bodies, private sector) and settings (e.g. dedicated international standard setting organizations, private sector consortia, or the marketplace) ${ }^{78}$ This diversity is illustrated by the wide variety of bodies and standards mentioned by delegation at the WTO in the context of STC discussions (See Annex 1). At its core, international standard setting governance relates to solving coordination problems between governments and private sector actors, over different types of externalities (e.g. positive network externalities, arising from technological compatibility and interoperability). ${ }^{79}$ The rationale for a particular setting - for example, setting standards by technical committee in an international organization as opposed to leaving it to the market place - depends on the type of standard being developed and the externalities it would seek to address (e.g. addressing health or safety risks may involve governments). ${ }^{80}$ Focusing on product compatibility standards, Farrell and Saloner (1988) showed that coordination was more likely to be achieved through negotiation in committees, as compared to unilateral market leadership, although the market would achieve coordination more rapidly.

${ }_{74}^{74}$ WTO (2011b) and WTO (2011a).

75 WTO (2000b).

${ }^{76}$ Article 1.3 of the TBT Agreement states: "All products, including industrial and agricultural products, shall be subject to the provisions of this Agreement". On the other hand, the SPS Agreement has a much narrower scope, which may mean that naming bodies is more appropriate in that context.

77 WTO (2000b).

${ }^{78}$ Abbot \& Snidal (2001), Mattli \& Büthe (2003), Mattli \& Büthe (2011).

${ }^{79}$ Farrell \& Saloner (1988), Mattli \& Büthe (2003), Abbot \& Snidal (2001).

80 WTO (2009b), Abbot \& Snidal (2001). 
4.3. The constitution and nature of the bodies designated to represent governments in international standard setting contexts (e.g. in ISO and IEC) varies from country to country, including in terms of the balance between government and stakeholder involvement (especially private sector). For instance, the private sector American National Standards Institute (ANSI) represents the United States at ISO and IEC, while European countries are represented by quasigovernmental national standardizing bodies (e.g. British Standards Institute, Afnor). Thus, private sector actors are involved to varying degrees in setting international standards, through participation in national bodies and sometimes in their own right. There are many examples of standards developed by private sector bodies which come to constitute international standards in time, either through ex-post endorsement by international organizations ${ }^{81}$ or by virtue of becoming a de facto market requirement. ${ }^{82}$ These differences in how governments and the private sector participate in international standard setting pose a number of possible challenges for governance.

4.4. At the national level, because domestic standardizing bodies vary in structure and resources, their influence on international standard setting processes will vary. These bodies, along with private sector stakeholders, are arguably most concerned with minimizing their domestic switching costs as a result of standardization. ${ }^{83}$ Therefore this is a risk of capture or bias in international standard setting. ${ }^{84}$ On the other side, differences in resources, size of economies, level of private sector development and involvement, and scientific and technological capacity can structurally disadvantage small developing countries in the international standard setting process. Furthermore, the fact that different arms of the same governments are involved in the governance process as setters and users of international standards opens the door to national coordination problems. For example, an international standard might be endorsed by the national standardizing body, but not used by policy makers or regulators, due to being inappropriate or ineffective for the policy objectives at hand. Finally, governments might be tempted not to follow an international standard in a given regulatory context as a way of protecting domestic producers ("policy substitution"). ${ }^{85}$ From this perspective, the flexibility inherent in the TBT Agreement on the use of international standards could conceivably be misused as a way to erect trade barriers.

4.5. In the past couple of paragraphs we have sought to characterize international standards setting governance and potential associated challenges. With all this in mind, it is interesting to consider the contribution of the WTO in this respect. The work of TBT Committee, in particular the Six Principles of the Committee Decision can be seen as a response to at least some of these governance challenges. The need to improve participation of developing countries in particular has been repeatedly highlighted in the TBT Committee. Moreover, the findings of the Appellate Body in relation to international standards (Annex 3) provide useful guidance for setting international standards relevant to the TBT context.

4.6. But is it realistic to assume that international standardizing governance can be transparent, open (at all stages of standards development), impartial, effective, coherent, cater to developing country needs - and deliver the highest level of technical content that the market demands? Does the pursuit of openness, in the all-or-nothing, consensus-driven WTO sense - work in the international standard-setting context? Or will a common denominator approach both dilute technical content, slow down the process, and lead to the fragmentation of the standard-setting processes into private, domestic or regional tracks - thus undermining regulatory alignment between countries.

4.7. Against this backdrop and looking ahead, we suggest a more simplified vision for governance of international standards setting. In particular, we argue for greater focus on actual substantive content of the standard, in particular its scientific underpinnings (confidence in the technical content), and the manner in which it is developed (good procedures). We suggest that focusing on these two aspects in particular may help address the aforementioned governance challenges, and thus ease tensions in the trade context (including WTO work). Improving the procedures by which

${ }^{81}$ Hawkins, Mansell \& Skea (1995).

${ }^{82}$ For example, the Portable Document Format (PDF) developed by Adobe won markets, and emerged as an "international standard" document format. Subsequently, in 2005 ISO incorporated the PDF into an ISO standard: the ISO 19005 series, Document management -- Electronic document file format for long-term preservation. (PDF/A-1, PDF/A-2, PDF/A-3).

${ }_{83}$ Mattli \& Büthe (2011).

${ }^{84}$ Mattli \& Büthe (2003), Abbot \& Snidal (2001).

${ }^{85}$ WTO (2012b). 
standards are set could help promote better national coordination, likewise focusing minds on particular scientific issues and related policy questions could create a fulcrum for coordination. Furthermore, emphasis on scientific evidence and technical content, and good underlying procedures can counteract bias or capture. Regarding policy substitution, standards emerging from open and transparent procedures, and backed by state of the art science are difficult to ignore (as 'not relevant'), making it harder for governments to discount them with the purpose of affording protection to their markets. Bringing these two aspects to the fore in any given standard should enhance the use of that standard by governments, thus promoting regulatory alignment and reducing unnecessary barriers to international trade.

\subsection{Technical Content promotes confidence}

4.8. Confidence in the technical content of the standard is crucial. A good international standard will reflect state-of-the-art scientific and technological developments. Indeed, in WTO TBT Committee work, Members have stressed the importance of international standardizing bodies taking into account scientific and technological developments in the elaboration of standards.86 Moreover, the TBT Agreement itself states that when assessing the risk that a given technical regulation (or conformity assessment procedure) is aimed at mitigating, one relevant element of consideration is "available scientific and technical information".87 Thus, confidence in the scientific integrity and quality of the standard will promote its widespread use and will contribute to convergence. Recalling the Committee Decision, the need for strong technical content relates most clearly to the principles of Effectiveness and Relevance.

4.9. Scientific content of a standard is of importance from another point of view too. Even if the regulator neither participates nor influences the standards development process - she might, conceivably, have confidence in the science - particularly if the international standard-setting body is known to the regulator, or has a certain reputation - or, in the words of the TBT Agreement, is considered by the regulator as a "recognized body". In that case, the regulator may not worry too much about not having participated or even influenced the process. She may have enough confidence in the international community of experts in a particular field to set objective requirements based on sound mathematics, physics and/or chemistry that is incorporated in the standard. In this sense, a well-developed international standard becomes a tangible form of technology transfer as envisaged in the preamble of the TBT Agreement, and particularly valuable for those countries that do not have the resources to either participate or develop standards themselves. ${ }^{88}$ Moreover, as alluded to above, ensuring technical quality of standards is one way that bodies can be 'recognized' for their activities in standardization by WTO Members, due to widespread use of the standard, even when a body only develops only one high quality standard.

4.10. Conversely, we argue that when standard-setting moves away from science and technology, its value as an international basis for regulation is more open to question. This is because while governments use regulation to pursue a certain policy (protection of environment, health, national security, etc.), and they use international standards as an instrument to achieve their objectives, governments themselves must ultimately make policy decisions. ${ }^{89}$ A standard-setting body that develops policy will very quickly face questions of legitimacy. Policy is the realm of governments, and policy choices may (for legitimate reasons) vary from country-to-country depending on different preferences, attitude to risk, and even social values. So while minds may be usefully focused on establishing the maximum level of lead paint in toys - and while, admittedly, there may be disagreements at the technical level on this - it remains precisely that: technical.

4.11. But what happens when the technical content is less tangible? Take, for example, the issue of social responsibility and ISO 26000. This is a standard aimed at providing guidance related to operationalizing social responsibility. ${ }^{90}$ This standard contains a somewhat awkward disclaimer to the effect that does not constitute a relevant international standard under the WTO TBT

${ }^{86}$ Principle 4 on Effectiveness and Relevance, WTO (2011c), p.48.

87 In the TBT Agreement, this is phrased in terms of the "risk of non-fulfilment" (Article 2.2 of the TBT Agreement).

${ }^{88}$ Preamble of the TBT Agreement (eighth recital). We note that this point should not be taken as an argument against participation in international standard-setting activities.

89 Principle on "Effectiveness and Relevance" states that an international standard needs to reflect scientific and technological developments in various countries (WTO (2011c), p.48).

${ }^{90}$ For more information on ISO 26000 - Social Responsibility, see: http://www. iso.org/iso/home/standards/iso26000.htm. 
Agreement. ${ }^{91}$ To begin with, this appears symptomatic of discomfort amongst national standards bodies about the relationship between WTO disciplines and ISO 26000: would the fact that this standard was developed by the ISO, now mean that Members had a strong encouragement to use this particular standard if they pursue legislation aimed at promoting social responsibility? The disclaimer would seem to flag that the standard in question may not be "relevant" for some Members - but, in doing so, it detracts from the international applicability (hence relevance) of the standard per se - and it could also, we argue, detract from status of the entity that produced it as having recognized activities in standardization. In part, this boils down to the intangibility of the matter itself: we may all agree that social responsibility is a good thing and that international dialogue is certainly beneficial to promote mutual understanding. But that is not the same as saying that it is possible to achieve an international benchmark in the same way as it is, for example, possible to achieve consensus on a toxicity limit for lead paint in toys.

4.12. However, as mentioned in the context of governance challenges, a sound focus on science and technical content is no panacea. Despite being a technical process driven by objective evaluation of scientific evidence and reconciliation of engineering arguments, international standard setting is to a certain degree influenced by politics. ${ }^{92}$ While it may not be the case that the most powerful states simply write international standards, powerful states may have disproportionate influence due to size of their economies, level of private sector development and involvement, and scientific and technological capacity. There is a risk that self-interested national bodies participating in a technical committee could produce a standard that is biased to the interests of a group of countries or firms. From the trade perspective, such standards can become obstacles because they are not a basis for global alignment of regulation. Given this reality, the procedures and processes used to develop a standard take on ever more importance.

\subsection{The procedure used to develop the standard}

4.13. The how is essential. The Appellate Body has stated that it is the characteristics of the body approving the standards which lends the standard its "international character", and makes a standard relevant. ${ }^{93}$ Moreover, processes are very much related to a number of the Committee Decision principles, including Openness, Impartiality and Consensus, Transparency, Coherence and the Development Dimension. If the development process of an international standard favors the preferences of one country/region over another, or if it is skewed to one set of interests, this will have implications on its use and "relevance" to the broader WTO membership. Broad stakeholder involvement will boost the beneficial, confidence-building aspects of standards. Furthermore, transparency and accountability are of crucial importance in standards setting processes, whether at the national or international level. ${ }^{94}$ Transparency applies across the standard setting process, from access to information needed to follow technical committees, to transparency decision making procedures.

4.14. We have discussed earlier in this paper the importance attributed to procedures in very specific cases. Lack of opportunity to influence the process and thereby the outcome (the standard) may be undermined if a Member's participation is hampered. Moreover, even where there is participation, it is important that the process by the standard is crafted is neither biased nor perceived to be so (e.g., by unduly giving some groups more weight than others). This may be sufficient grounds for a Member to feel uncomfortable with the end-result. ${ }^{95}$ Indeed, the Appellate Body in the US - Tuna II report, stressed that bodies which include broad participation of

91 This disclaimer reads: "However, for the purposes of the Marrakech Agreement establishing the World Trade Organization (WTO), it is not intended to be interpreted as an 'international standard', 'guideline' or 'recommendation', nor is it intended to provide a basis for any presumption or finding that a measure is consistent with WTO obligations. Further, it is not intended to provide a basis for legal actions, complaints, defences or other claims in any international, domestic or other proceeding, nor is it intended to be cited as evidence of the evolution of customary international law." (ISO/FDIS 26000:2010 (E), lines 158-163).

92 Mattli \& Büthe $(2003,2011)$.

93 US - Tuna II, WT/DS381/R, para. 353.

${ }^{94}$ In the latest Triennial Review Report (November, 2012), the TBT Committee agreed to discuss "how relevant bodies involved in the development of standards - whether at the national, regional or international level - provide opportunity for public comment". (WTO (2012a), paragraph 9(a)).

${ }^{95}$ By way of example, in relation to automobile tyre standards India has states that UNECE is not a relevant standard (since India is not a signatory to UNECE), and that ISO is the relevant international standards-setting body in this context (Item 60). In another case, the United States questioned the relevance of ICAO standards for the transport of lithium batteries, due to the process by which they were crafted (Item 97). 
Members, are open ${ }^{96}$ to any Member that wishes to take part, and which follow the Committee Decision in the standard setting process, are more likely to have "recognized activities" in standardization, and thus be considered an international standardizing organization for the purposes of the TBT Agreement. ${ }^{97}$ Conversely, we can argue the opposite: a flawed process may be less likely to confer relevance.

4.15. On openness the Appellate Body (referencing from the Committee Decision) has stressed this entails openness at all stages of standards development, not just at one point in the process or one point in time. Moreover, there must not be restrictions on membership (by WTO Members) ${ }^{98}$, and that accession to the body should be practically automatic. ${ }^{99}$ However, in practice, the way standards are currently set (even under the best conditions) does not necessarily provide for this degree or kind of openness. First, many international standardizing bodies impose membership fees and requirements which might hinder certain countries from taking part in decision making processes. Moreover, there are often transition periods for new members; accession is far from automatic. Therefore, even putting aside the issue of expertise, if a WTO Member cannot afford the fees, or is undergoing a protracted accession process, the body is by this strict reading not "open". In this vein, it could be argued that many of the bodies generally viewed as international standardizing bodies in the TBT area would be precluded from having recognized activities in standardization, and thus from setting "relevant" international standards.

4.16. Standard-setting is a time sensitive process; it is not clear how openness at all stages can, from a very practical point of view, be achieved. The example of standards for product and organizational carbon footprints is illustrative. International standardizing bodies, already late to the game, have so far been unable to develop an international standard in due time due to disagreements between Members in the technical committee. Further delay may mean that fragmented private and national standards will become more entrenched in the marketplace - and the opportunity to invest in an international standard is lost.

4.17. As inferred above, mere opportunity for comment many not always be enough. ${ }^{100}$ It is also important that participation - when it takes place - is effective and efficient; in other words, the "who" matters. Participation of non-experts with limited knowledge will not necessarily promote the development of high quality standards (with good technical content). Beyond expertise, effective participation also involves an element of national coordination, to ensure that standard that one endorses is relevant for regulators and policy makers at home.

4.18. Yet participation in all international standards development processes is not a realistic objective for any Member - developed or developing. Members therefore need to choose to focus scarce resources for participation on those international standard bodies that are most relevant to their economies. This choice will be all the more stark for developing countries. ${ }^{101}$

4.19. Following on this point, structural imbalances between governments can lead to developing counties, particularly least developed countries, being practically excluded for decision making procedures, which can raise questions about non-representativeness and inequity. Substantial technical expertise and resources are prerequisites for effective participation in international standard setting. For countries which lack in these respects, it may be necessary to find new ways of increasing influence of developing countries in standard setting, beyond a seat at the table. For

${ }^{96}$ Principle 2 on "Openness" is an important term in this context. The TBT Committee has stressed that "openness" applies with respect to the participation at the policy development level and at every stage of standards development and that all relevant bodies of WTO Members should be provided with meaningful opportunities to contribute to the elaboration of an international standard. (WTO (2011c), p.47)

${ }^{97}$ See infra notes 28 - 31, Section III.A

${ }^{98}$ WT/DS381/AB/R, para. 364.

${ }^{99}$ I bid., para. 386

100 "Participation" is used in a broad sense, including both physical participation in the work of setting and international standard (for instance in a working group or technical committee) and other means of participation, such as by electronic means.

101 As early as 1997 delegations to the TBT Committee agreed to explore ways and means of enhancing Members' awareness of, and participation in, the work of international standardizing bodies. In 2001 (at the Doha Ministerial Conference), Members urged the Director-General of the WTO to cooperate with international standardizing bodies and other institutions with a view to according priority to the effective participation of least-developed country (LDCs) Members and facilitating the provision of technical and financial assistance for this purpose WTO (2001b), para. 5.3). For further efforts by Members in this regard, see also WTO (2006), 14 November 2006, para. 77 and WTO (2012a), para. 8(b) on the "Development Dimension". 
instance, one could contemplate decision making processes whereby developing countries have some additional power or say in the outcome, or a situation whereby experts from developed countries could be assigned to assist or represent a particular developing country in technical committees.

\section{CONCLUSION}

5.1. Above we stress the importance of technical content and procedure. We see these aspects as vital for addressing possible challenges in international standards governance and tensions in WTO work, with a view to promoting greater regulatory alignment.

5.2. We don't think full and slavish adherence to the Six Principles is a realistic proposition. Inevitably, international standardizing bodies will need to balance the need for high-level technical content with the reality of a rapidly evolving market place, where governments are different and cater to consumer preferences in different ways, and scientific progress is dynamic. It is unlikely, we think - and perhaps even undesirable - that Members will anytime soon narrow the policy space (flexibility) in the WTO TBT Agreement that we have described above, whether through negotiations or committee work (let alone dispute settlement). Seen through the lens of the TBT Agreement (trade-restrictiveness) the choice of a "relevant" international standard in different situations is likely to continue to create tension across all areas of the WTO's mandate. But this does not mean that there is no scope for further progress. Instead, we turn to the broader question of international standard setting governance for answers. Addressing challenges in that governance context will help international standards to serve their envisaged role of promoting order in the marketplace and increasing alignment between regulatory systems.

5.3. In our view, international standardizing bodies need to strive for better international standards governance - not aspire for perfection. Focus on technical content is a good vaccine for political bias. And, in terms of process, openness and transparency will breed trust, confidence and increase uptake. Nevertheless, the responsibility for the successful implementation of the TBT Agreement lies squarely with WTO member governments - not with standardizing bodies. Overcoming international standards governance challenges will support WTO members' endeavours to achieve legitimate policy objectives while, at the same time, bringing their regulations closer.

\section{REFERENCES}

Abbot, K.W. \& Snidal, D. (2001), International standards and international governance, J ournal of European Public Policy, Vol. 8, No. 3, pp. 345-370.

Farrell, J. \& Saloner, G. (1988), Coordination through committees and markets, RAND Journal of Economics, Vol. 19, No. 2, pp. 235-252.

Fliess, B., Gonzalez. F., Kim, J. \& Schonfeld, R. (2010), The Use of International Standards in Technical Regulation, OECD Trade Policy Papers, No. 102.

Hawkins, R.W., Mansell, R. \& Skea, J. (1995), Standards, Innovation and Competitiveness: The Politics and Economics of Standards in Natural and Technical Environments, Edward Elgar.

Mattli, W. \& Büthe, T. (2003), Setting International Standards: Technological Rationality or Primacy of Power?, World Politics, Vol. 56, No. 1, pp. 1-42.

Mattli, W. \& Büthe, T. (2011), The New Global Rulers: The Privatization of Regulation in the World Economy, Princeton University Press, New Jersey.

Wijkström, E. \& McDaniels, D. (2012), Managing Conflict in the WTO Without Formal Disputes: Enhancing the Use of Notifications and Specific Trade Concerns, Presentation at 2012 WTO Public Forum. Available at: http://www. entwined.se/download/18.386979f513ala34373990/1349160140678/4.+Enhancing+t he+Use+of+Notifications+and+Specific+Trade+Concerns. pdf 
Wolfe, R. (2013), Does sunshine make a difference? How transparency brings the trading system to life (Mimeo).

WTO (1995 - 2012), Minutes of meetings of the Committee on Technical Barriers to Trade: G/TBT/M/1-58.

WTO (1997), First Triennial Review of the Operation and Implementation of the Agreement on Technical Barriers to Trade, 19 November 1997 (97-5092), (G/TBT/5).

WTO (2000a), Second Triennial Review of the Operation and Implementation of the Agreement on Technical Barriers to Trade, 13 November 2000 (00-4811), (G/TBT/9).

WTO (2000b), Good Practice for the Acceptance of results of Conformity Assessment, Second Triennial Review of the Agreement: Contribution from Australia, 28 July 2000, (00-3117), $\mathrm{G} / \mathrm{TBT} / \mathrm{W} / 138$.

WTO (2001a), Ministerial Declaration adopted on 14 November 2001, Ministerial Conference, Fourth Session, Doha 9-14 November 2001, WT/MIN(01)/DEC/1.

WTO (2001b), Implementation-related issues and concerns, decision of 14 November 2001, Ministerial Conference, Fourth Session, Doha 9-14 November 2001, WT/MIN(01)/17.

WTO (2003), Third Triennial Review of the Operation and Implementation of the Agreement on Technical Barriers to Trade, 11 November 2003 (03-5999), (G/TBT/13).

WTO (2006), Fourth Triennial Review of the Operation and Implementation of the Agreement on Technical Barriers to Trade, 14 November 2006, (06-5503) (G/TBT/19).

WTO (2008a), Committee on Technical Barriers to Trade, Good Regulatory Practice, 22 February 2008, J OB(08)/7.

WTO (2008b), Committee on Technical Barriers to Trade, Summary Report of the TBT Workshop on Good Regulatory Practice, 18-19 March 2008, 6 J une 2008 (08-2671), G/TBT/W/287.

WTO (2009a), Fifth Triennial Review of the Operation and Implementation of the Agreements on Technical Barriers to Trade, 13 November 2009 (09-5651), G/TBT/26.

WTO (2009b), Standards and the WTO TBT Agreement, 9 March 2009 (09-1179), J OB(09)/15.

WTO (2011a), Market Access for Non-agricultural Products, International StandardsCommunication from Mauritius on behalf of the ACP Group, Negotiating Group on Market Access, 14 January 2011, JOB/MA/80.

WTO (2011b), Market Access for Non-agricultural Products, International StandardizationCommunication from the delegations of the European Union, India, Malaysia, Norway, the Philippines, Switzerland and Thailand, Negotiating Group on Market Access, 19 January 2011, JOB/MA/81.

WTO (2011c), Decisions and recommendations adopted by the WTO Committee on Technical Barriers to Trade since 1 J anuary 1995, 9 J une 2011 (11-2857), G/TBT/1/Rev.10.

WTO (2011d), Committee on Technical Barriers to Trade, Compilation of Sources on Good Regulatory Practice, 13 September 2011, (11-4394), G/TBT/W/341.

WTO (2012a), Sixth Triennial Review of the Operation and Implementation of the Agreements on Technical Barriers to Trade, 29 November 2012 (12-6612), G/TBT/32.

WTO (2012b), World Trade Report 2012 - Trade and Public policies: A closer look at non-tariff measures in the $21^{\text {st }}$ Century, available at:

http://www.wto.org/english/res_e/booksp_e/anrep_e/world_trade_report12_e.pdf 
WTO (2013), Analytical Index.

\section{WTO Panel Reports and Appellate Body Reports}

EC Measures - Concerning meat and meat products (Hormones), Report of the Panel, 18 August 1997 (97-3368), WT/DS26/R/USA.

EC Measures - Concerning meat and meat products (Hormones), Report of the Appellate Body (AB-1997-4), 19 January 1998, WT/DS26/AB/R and WT/DS48/AB/R.

European Communities - Trade Description of Sardines, Report of the Panel, 29 May 2002 (022894), WT/DS231/R.

European Communities - Trade Description of Sardines, Report of the Appellate Body (AB 2002-3), 26 September 2002 (02-5137), WT/DS231/AB/R.

United States - Certain Country of Origin Labelling (Cool) Requirements, Reports of the Appellate Body (AB-2012-3), 29 June 2012(12-3450), WT/DS384/AB/R and WT/DS386/AB/R.

United States - Measures Affecting the Production and Sale of Clove Cigarettes, Report of the Appellate Body (AB-2012-1), 4 April 2012 (12-1741), WT/DS406/AB/R.

United States - Measures Affecting the Production and Sale of Clove Cigarettes, Report of the Panel, 2 September 2011 (11-4166), WT/DS406/R.

United States - Measures concerning the importation, marketing and sale of tuna and tuna products, Report of the Panel, 15 September 2011 (11-4239), WT/DS381/R.

United States - Measures concerning the importation, marketing and sale of tuna and tuna products, Report of the Appellate Body (AB 2012-2), 16 May 2012 (12-2620), WT/DS381/AB/R. 


\section{ANNEX I : BODI ES REFERENCED I N SPECI FIC TRADE CONCERNS DISCUSSION}

- $\quad$ Advanced Television Systems Committee (ATSC) ATSC/52, the Digital Audio Compression Standard

- American Society for testing and Materials (ASTM) International

- Asia-Pacific Economic Cooperation (APEC) Chemical Dialogue

- Common Criteria Recognition Agreement (CCRA)

- Convention on International Trade in Endangered Species (CITES)

- $\quad$ EU Good Manufacturing Practice (GMP)

- European Committee for Standardisation (CEN)

- European Cooperation for Accreditation (EA)

- FAO/WHO Codex Alimentarius Commission (Codex)

- Institute of Electrical and Electronics Engineers (IEEE)

- Intergovernmental Panel on Forests (IPF)

- International Accreditation Forum (IAF)

- International Civil Aviation Organization (ICAO)

- International Conference on Harmonisation of Technical Requirements for Registration of Pharmaceuticals for Human Use $(\mathrm{ICH})$

- International Council of Chemical Associations (ICCA) HPV Program

- International Electrotechnical Commission (IEC)

- International Foundation for Organic Agriculture Movements (IFOAM)

- International Laboratory Accreditation Cooperation (ILAC)

- International Maritime Organization (IMO)

- International Olive Oil Council (IOC)

- International Organization for Standardization (ISO)

- International Organization of Legal Metrology (OIML)

- International Organization of Vine and Wine (OIV)

- International Tropical Timber Agreement (ITTA)

- J oint FAO/WHO Expert Committee on Food Additives (JECFA)

- Nanomaterials Working Group of the International Cooperation on Cosmetics Regulation (ICCR)

- Organization for Economic Cooperation and Development (OECD)

- Pharmaceutical Inspection Convention and Pharmaceutical Inspection Co-operation Scheme (PIC/S)

- UN Globally Harmonized System of Classification and Labelling of Chemicals (GHS)

- United Nations Economic Cooperation for Europe (UNECE)

- United Nations Intergovernmental Forum on Forest (IFF)

- WHO Framework Convention on Tobacco Control (FCTC)

- World Health Organization (WHO)

- World Organization for Animal Health (OIE)

- World Wine Trade Group (WWTG) Agreement on Requirements for Wine Labelling

- Worldwide System for Conformity Testing and Certification of Electrotechnical Equipment and Components (IECEE) 


\section{Title}

Bodies Referenced

Argentina - Resolution 453/2010 establishing mechanisms in order to eliminate dangers arising from the use of inks with a high lead content in graphic products

Argentina - Testing Requirements for Imported Toys (G/TBT/N/ARG/51, Adds. 1-4 and Suppl.1)

Australia - Tobacco Plain Packaging Bill 2011(G/TBT/N/AUS/67)

Bahrain - Motor Vehicles - General Requirements

Belgium - Royal Decree limiting the Marketing, Manufacture and Use of some Hazardous Substance: Asbestos

Brazil - Canned Sardines - Ministerial Act № 406, 10 August 2010 (G/TBT/N/BRA/386)

Brazil - Disposition (Portaria) no 371, December 29th 2009 and Annex; INMETRO approves Conformity Assessment Requirements for Security of

Electronic Appliances (G/TBT/N/BRA/343 and Add.1)

Brazil - Draft Resolution No. 112, 29 November 2010; maximum levels of tar, nicotine and carbon monoxide permitted on tobacco products and

prohibition of additives (G/TBT/N/BRA/407)

Brazil - Health products registration (G/TBT/N/BRA/328)

Brazil - Regulations on Identification and Quality Standards of Ethyl Alcohol and other Spirits

Brazil - Wines

Brazil - Toys

Canada - Bill C-32 amendment to Tobacco Act

Canada - Canadian Ship Inspectorate Directorate

Canada - Compositional requirements for cheese (G/TBT/N/CAN/203 and Add.1)

China - Compulsory Certification (CCC) System

China - Draft Standards on Lithium Batteries for Mobile Phones

China - Energy efficiency and energy efficiency grades for copy machines

China - GB/T xxxx-xxxx, Information Security Technology -- Office Devices Security and YD/T xxxx-xxxx, High spectrum efficiency and high

throughput wireless LAN technical requirements

China - Lighting and Light-Signalling Devices for Motorcycles (G/TBT/N/CHN/721 and Suppl.1)

China - Measures for the Administration of Certification Bodies (G/TBT/N/CHN/798 and G/TBT/N/CHN/798/Suppl.1)

China - National Standard of the P.R.C., Direction for Use and Labels for Carpets (G/TBT/N/CHN/624)

China - Proposed Regulations on Information Security

China - Regulations of the PRC on Certification and Accreditation (promulgated by Decree No. 390 of the State Council of the PRC on

3 September 2003)

China - Requirements for information security products (including, inter alia, the Office of State Commercial Cryptography Administration (OSCCA)

1999 Regulation on commercial encryption products and its on-going revision and the Multi-Level Protection Scheme (MLPS)

China - Textiles and Apparel (G/TBT/N/CHN/427)

China - The Provisions on the Environmental Administration of New Chemical Substances (Amendments) (G/TBT/N/CHN/210/Rev.1)

China - WAPI standard requirements

China - Wines

China - General Standard for the Labelling of Pre-packaged Alcoholic Beverages

Chinese Taipei - Anti-theft Regulations for Vehicles

Colombia - Alcoholic beverages (G/TBT/N/COL/121 and Adds.1-3)

Colombia - Draft Decree Establishing Provisions to Promote the Use of Biofuels (G/TBT/N/COL/96 and Adds. 1-4 and Add.4/Rev.1

Colombia - Draft Resolution of the Ministry of Transport Issuing the Technical Regulation for public transport (G/TBT/N/COL/164,

G/TBT/N/COL/164/Add.1)

ILAC, ISO

ILAC

FCTC

UNECE

None

None

IEC

FCTC

ISO

JECFA

OIV

ILAC, ISO

FCTC, JECFA, FDA IEC

Codex

IECEE

None

None

IEEE, ISO, IEC

UNECE

ISO

ISO

ISO, IEC, CCRA

IEC, ILAC, IECEE

CCRA

ISO

OECD, GHS

IEC

Codex, OIV

Codex

UNECE

None

E-10 fuel standard UNECE 
Colombia - Quality and I dentity Requirements for Distilled Spirits

Dominican Republic - Draft of the Technical Regulation "Categorization of Alcoholic Beverages" (G/TBT/N/DOM/143 and G/TBT/N/DOM/143/Add.1) Ecuador - Certification of Ceramic Tiles (Resolutions 17 and 18 of CONCAL)

Ecuador - Test report and certificate of conformity for industrial products including tyres, steel products and automobile components

Egypt - National Standards on the Certification of the Hide of Leather Footwear

El Salvador - Law on hygienic production of milk and milk products and the regulation of their sale

European Communities - Accreditation and market surveillance relating to the marketing of products (G/TBT/N/EEC/152)

European Communities - Compulsory Indication of the Labelling of Certain Foodstuffs Produced from GMOs

European Communities - Directive on Measuring Instruments

European Communities - Green Paper on Agricultural Product Quality Policy

European Communities - Marketing Standards for Olive Oil

European Communities - Measures on the Use of Asbestos in Brick Lining

European Communities - Production and Labelling of Organic Products

European Communities - Reference Standard under the Electromagnetic Capability Directive

European Communities - Regulation on Aircrafts

European Communities - Standards related to Gas Connection Valves

European Union - Council Regulation (EC) No 1099/2009 of 24 September 2009 on the protection of animals at the time of killing

European Union - Directive 2002/95/EC on the Restriction of the Use of certain Hazardous Substances in Electrical and Electronic Equipment

(RoHS) and Directive 2002/96/EC on Waste Electrical and Electronic Equipment (WEEE) (G/TBT/N/EEC/247, Add.1 and G/TBT/Notif.00/310,

Corr.1)

European Union - Directive 2004/24/EC on Traditional Herbal Medicinal Products

European Union - Directive 2011/62/EU of the European Parliament and of the Council amending Directive 2001/83/EC on the Community code

relating to medicinal products for human use, as regards the prevention of the entry into the legal supply chain of falsified medicinal products

(G/TBT/N/EEC/246, G/TBT/N/EEC/246/Add.1)

European Union - Directive on eco-design requirements for household dishwashers (G/TBT/N/EEC/321), European Union - Directive on eco-design requirement for fans (G/TBT/N/EEC/323)

European Union - Draft Commission Regulation implementing Directive 2009/125/EC of the European Parliament and of the Council with regard to ecodesign requirements for air conditioners and comfort fans G/TBT/N/EEC/362)

European Union - issue with respect of honey containing pollen from genetically modified maize MON810, Ruling from ECJ

European Union - Poultry Meat

European Union - Provisions on limit values for allergenic substances in children's products (2009/48/EC) (G/TBT/N/EEC/184 and

G/TBT/N/EEC/184/Add.1)

European Union - Regulation (EC) No.1222/2009 Labelling of Tyres, Commission Regulation (EC) No.228/2011, No.1235/2011

European Union - Regulation on Classification, Labelling and Packaging of Substances and Mixtures (ATPS and CLP) (G/TBT/N/EEC/151 and

Adds.1-2; G/TBT/N/EEC/212 and Adds.1-3; G/TBT/N/EEC/163 and Adds.1-2, Add.1/Corr.1)

European Union - Regulation on the Registration, Evaluation and Authorization of Chemicals (REACH) (G/TBT/N/EEC/52 and Adds.1-6;

Add.3/Rev.1; G/TBT/N/EEC/295 and Add.1; G/TBT/N/EEC/297; G/TBT/N/EEC/333-6)

European Union - Seal products (G/TBT/N/EEC/249 and Adds. 1-2; G/TBT/N/EEC/325)

European Union - Toys

European Union - Common authorisation procedure for food additives, food enzymes and food flavoring

France - Regulation on Asbestos

France - Unique Requirements for Ride-on Lawn Mowers

India - Food Safety and Standards Regulation - Food labelling requirements (G/SPS/N/IND/69)

\begin{tabular}{|c|}
\hline Bodies Referenced \\
\hline None \\
\hline Codex \\
\hline ISO \\
\hline ISO \\
None \\
\hline Codex \\
\hline ILAC, IAF, ISO, EA \\
\hline None \\
\hline OIML \\
\hline UNECE, Codex \\
\hline Codex, IOC \\
\hline None \\
\hline Codex \\
\hline IEC \\
\hline ICAO \\
\hline CEN \\
\hline OIE \\
\hline IEC \\
\hline PIC/S, ICH, ILAC, IAF \\
\hline WHO, ICH \\
\hline OECD, Codex, APEC, \\
\hline GHS, ICCA \\
\hline CITES \\
\hline ISO, ASTM \\
\hline Codex \\
\hline None \\
\hline ISO, CEN \\
\hline Codex \\
\hline WHO, ISO \\
\hline Codex \\
\hline OSO, CEN \\
\hline ONECE \\
\hline
\end{tabular}


India - New Telecommunications related Rules (Department of Telecommunications, No. 842-725/2005-VAS/Vol.III (3 December 2009); No. 10-

15/2009-AS-III/193 (18 March 2010); and Nos. 10-15/2009-AS.III/Vol.II/(Pt.)/(25-29) (28 July 2010); Department of Telecommunications, No.

10-15/2009-AS.III/Vol.II/(Pt.)/(30) (28 July 2010) and accompanying template, "Security and Business Continuity Agreement")

India - Notification on protective headgear

India - Pneumatic tyres and tubes for automotive vehicles (G/TBT/N/IND/20 and Add.1; G/TBT/N/IND/40 and Rev.1)

India - Regulation on Second Hand Vehicles and New Vehicles

India - Restriction on (Chinese) Toys

India - Toys and Toy Products (Compulsory Registration) Order

India - Regulation on Medical Devices

Indonesia - Draft Decree of Minister of Industry on Mandatory Implementation of Indonesia National Standard for electrolysis tin coated thin stee

sheets (G/TBT/N/IDN/46)

Indonesia - Labelling Regulations (Ministry of Trade Regulation 62/2009 and 22/2010) (G/TBT/N/IDN/47)

Indonesia - Technical Guidelines for the Implementation of the Adoption and Supervision of Indonesian National Standards for Obligatory Toy

Safety

Italy - Dairy products (G/TBT/N/ITA/13)

Japan - Legislation on Fishing Vessels

Korea - A Draft of Regulation for Measurement of Energy Efficiency of Tyres for Motor Vehicles, and Its Rating and Identification

(G/TBT/N/KOR/319, G/TBT/N/KOR/319/Add.1)

Korea - Beef

Korea - Good Manufacturing Practice requirements for cosmetics (G/TBT/N/KOR/301)

Korea - KS C IEC61646:2007 Standard for Thin-film Solar Panels

Korea - Labelling Standards for Food

Korea - Proposed Cosmetics Labelling and Advertisement Guidelines (G/TBT/N/KOR/308); KFDA draft Guidelines for Management of Nanomaterials

in Cosmetics

Korea - Regulation for Food Industry Promotion Act (G/TBT/N/KOR/204 and Suppl.1)

Korea - Regulation on Registration and Evaluation of Chemical Material (G/TBT/N/KOR/305)

Korea - Safety criteria for various products

Korea - Windows Energy Efficiency, Ministry of Knowledge Economy (MKE) Notification 2011-263, December 2011

Korea - Safety criteria for Miniature Fuses on Automatic Electric Control

Malaysia - Draft Protocol for Halal Meat and Poultry Production (G/TBT/N/MYS/23)

Mexico - Refusal of the National Water Commission to re-certify HDPE pipe products meeting quality/safety standards for piping set out in NOM

001 and NMX 241(G/TBT/N/MEX/206 and G/TBT/N/MEX/206/Add.1)

Mexico - Standard for Glazed Pottery Ware, Glazed Ceramic Ware and Porcelain Ware

Netherlands- "Vos" Bill on Wood Products

New Zealand - Proposal to introduce plain packaging of tobacco products in New Zealand (G/TBT/N/NZL/62)

Phillipines - Ceramic wall and floor tiles

Russian Federation - Draft on Technical Regulation of Alcohol Drinks Safety (published on 24 October)

South Africa - Liquor Products Act of 1989

Thailand - Health Warnings for Alcoholic Beverages GHS, OECD

UNECE

ISO

Codex 


\begin{tabular}{|c|c|}
\hline Title & Bodies Referenced \\
\hline Thailand - Labelling Requirement for Snack Foods & Codex \\
\hline Thailand - Mandatory Certification for Steel Products (G/TBT/N/THA/306 and Add.1) & ISO, IEC \\
\hline Thailand - Mandatory standards prepared by the Thai Industrial Standards Institute on carbon dioxide for medical use & None \\
\hline Thailand - Mandatory standards prepared by the Thai Industrial Standards Institute on Cold Reduced Carbon Steel Coil & None \\
\hline The People's Republic of China - Administration on the Control of Pollution Caused by Electronic Information Products & None \\
\hline $\begin{array}{l}\text { Turkey - New Conformity Assessment Procedures for Pharmaceuticals (Circular issued by the Directorate General of Drugs and Pharmacy of the } \\
\text { Ministry of Health re: "Important Announcement regarding GMP Certificates") }\end{array}$ & WHO, GMP, PIC/S \\
\hline Ukraine - Draft Technical Regulation on the labelling of foodstuff (G/TBT/N/UKR/52) & Codex \\
\hline United States - Application of third party testing requirements; reducing third party testing burdens (G/TBT/N/USA/659) & ISO, IEC, ILAC \\
\hline United States - Care Labelling of Textiles & ISO \\
\hline United States - Children's jewellery & ISO \\
\hline United States - Conditions and Criteria for Recognition of Accreditation Bodies \& Laboratories for the Energy Star Program & ILAC, ISO \\
\hline United States - Consumer Product Safety Improvement Act (G/TBT/N/USA/421 and Add.1) & ISO, ILAC \\
\hline United States - Country of Origin Labeling for Dairy & Codex \\
\hline United States - Country of Origin Labelling & Codex \\
\hline United States - FCC Rules 96-493 on Broadcast Services; Television Broadcast Stations; TV Transmission Standards & ATSC \\
\hline United States - Federal Motor Vehicle Safety Standards : Tyre Pressure Monitoring System & UNECE \\
\hline United States - Fire Resistance of Mattresses and Bedding & ISO \\
\hline United States - Hazardous Materials: Transportation of Lithium Batteries (G/TBT/N/USA/518) & UNECE, ICAO, IMO \\
\hline United States - Olive Oil & Codex, IOC \\
\hline United States - Standard on Fire Detection and Alarm System Control Equipment & ISO \\
\hline United States - Standards of I dentity for Pisco and Cognac (G/TBT/N/USA/697) & None \\
\hline United States - Test procedures for high density discharge lamps & IEC,ISO, ILAC \\
\hline United States - Energy Conservation Program for Consumer Products: Test Procedure for Residential Central Air Conditioners and Heat Pumps & None \\
\hline United States - Tea Standards. & ISO \\
\hline United States - Measure on Refillable Lighters & ISO \\
\hline Viet Nam - Alcoholic Beverages & None \\
\hline
\end{tabular}


9 ANNEX III: SELECTED CONCEPTS RELEVANT TO PANEL/ APPELLATE BODY REASONING UNDER ARTICLE 2.4

\begin{tabular}{|c|c|}
\hline Concept & Description \\
\hline "relevant international standard" & (an international standard which) "bears upon, relates to, or is pertinent to..."102 (the measure in question). \\
\hline "consensus" & $\begin{array}{l}\text { "...the definition of a "standard" in Annex } 1.2 \text { to the TBT Agreement does not require approval by consensus for standards adopted by a } \\
\text { "recognized body" of the international standardization community."103 } \\
\text { "...even if not adopted by consensus, an international standard can constitute a relevant international standard." }{ }^{104}\end{array}$ \\
\hline "international standardizing body" & $\begin{array}{l}\text { "... a body that has recognized activities in standardization and whose membership is open to the relevant bodies of at least all } \\
\text { Members". }{ }^{105}\end{array}$ \\
\hline $\begin{array}{l}\text { "open to the relevant bodies of at least } \\
\text { all Members"; openness }\end{array}$ & $\begin{array}{l}\text { "... body will be open if membership to the body is not restricted. It will not be open if membership is a priori limited to the relevant } \\
\text { bodies of only some WTO Members."106 } \\
\text { "The question whether a body is "open" if all WTO Members or their relevant bodies can accede pursuant to an invitation has to be } \\
\text { decided on a case-by-case basis. It is conceivable that an invitation might indeed be a "formality". In our view, this would be the case if } \\
\text { the invitation occurred automatically once a Member or its relevant body has expressed interest in joining a standardizing body."107 } \\
\text { "Thus, in order for a standardizing body to be considered "international" for the purposes of the TBT Agreement, it is not sufficient for the } \\
\text { body to be open, or have been open, at a particular point in time. Rather, the body must be open "at every stage of standards } \\
\text { development"."108 }\end{array}$ \\
\hline $\begin{array}{l}\text { "recognized activities in } \\
\text { standardization" }\end{array}$ & $\begin{array}{l}\text { In interpreting "recognized activities in standardization", we will therefore bear in mind both the factual and the normative dimension of } \\
\text { the concept of "recognition". } 109 \\
\text { "... bo body with "recognized activities in standardization", does not need to have standardization as its principal function, or even as one of } \\
\text { its principal functions. At the same time, we note that the factual dimension of the concept of "recognition" would appear to require, at a } \\
\text { minimum, that WTO Members are aware, or have reason to expect, that the international body in question is engaged in standardization } \\
\text { activities."110 } \\
\text { "...in examining whether an international body has "recognized activities in standardization", evidence of recognition by WTO Members as } \\
\text { well as evidence of recognition by national standardizing bodies would be relevant."111 } \\
\text { "...recognition of a body's standardization activities may "be inferred from the recognition of the resulting standard, i.e. when its } \\
\text { existence, legality and validity [have] been acknowledged". While we regard the recognition of a body's standards by WTO Members and } \\
\text { national standardizing bodies as highly pertinent evidence that a body has recognized activities in standardization, we do not consider }\end{array}$ \\
\hline
\end{tabular}

102 WT/DS231/AB/R, paragraph 229-232

${ }_{103} \mathrm{WT} / \mathrm{DS} 231 / \mathrm{AB} / \mathrm{R}$, paragraph 227.

${ }^{104} \mathrm{WT} / \mathrm{DS} 231 / \mathrm{R}$, paragraph 7.90

${ }^{105} \mathrm{WT} / \mathrm{DS} 381 / \mathrm{AB} / \mathrm{R}$, paragraph 359. Original footnote removed.

${ }^{106} \mathrm{WT} / \mathrm{DS} 381 / \mathrm{AB} / \mathrm{R}$, paragraph 364.

107 WT/DS381/AB/R, paragraph 386

108 WT/DS381/AB/R, paragraph 374.

${ }_{109}$ WT/DS381/AB/R, paragraph 361.

${ }_{110} W T / D S 381 / A B / R$, paragraph 362. Original footnote removed.

$111 \mathrm{WT} / \mathrm{DS} 381 / \mathrm{AB} / \mathrm{R}$, paragraph 363. 


\begin{tabular}{|c|c|}
\hline & $\begin{array}{l}\text { that only a body whose standards are widely used can have recognized activities in standardization for the purposes of the TBT } \\
\text { Agreement." } 112 \\
\text { "As a result, the use of the plural "activities" does not necessarily imply that a body is, or has been, involved in the development of more } \\
\text { than one standard. As we see it, a body simply has to be "active" in standardization in order to have "activities in standardization"."113 } \\
\text { "...we find it difficult to see why an international organization that develops a single standard could not have "recognized activities in } \\
\text { standardization" if other evidence suggests that the body's standardization activities are recognized, for example, if a large number of } \\
\text { WTO Members participate in the development of the standard, acknowledge the validity and legality of the standard, or the body follows } \\
\text { the principles contained in the TBT Committee Decision." } 114 \\
\text { "...it seems to us that the larger the number of countries that participate in the development of a standard, the more likely it can be said } \\
\text { that the respective body's activities in standardization are "recognized"."115 }\end{array}$ \\
\hline TBT Committee Decision & $\begin{array}{l}\text { "We therefore consider that the TBT Committee Decision can be considered as a "subsequent agreement" within the meaning of Article } \\
31(3) \text { (a) of the Vienna Convention. The extent to which this Decision will inform the interpretation and application of a term or provision } \\
\text { of the TBT Agreement in a specific case, however, will depend on the degree to which it "bears specifically" on the interpretation and } \\
\text { application of the respective term or provision. In the present dispute, we consider that the TBT Committee Decision bears directly on the } \\
\text { interpretation of the term "open" in Annex } 1.4 \text { to the TBT Agreement, as well as on the interpretation and application of the concept of } \\
\text { "recognized activities in standardization"."116 }\end{array}$ \\
\hline "use as a basis" & $\begin{array}{l}\text { "...an international standard is used "as a basis for" a technical regulation when it is used as the principal constituent or fundamental } \\
\text { principle for the purpose of enacting the technical regulation."117 } \\
\text { "...there must be a very strong and very close relationship between two things in order to be able to say that one is "the basis for" the } \\
\text { other."118 }\end{array}$ \\
\hline $\begin{array}{l}\text { "ineffective means"; "inappropriate } \\
\text { means" }\end{array}$ & $\begin{array}{l}\text { "Thus, in the context of Article } 2.4 \text {, an ineffective means is a means which does not have the function of accomplishing the legitimate } \\
\text { objective pursued, whereas an inappropriate means is a means which is not specially suitable for the fulfilment of the legitimate objective } \\
\text { pursued. An inappropriate means will not necessarily be an ineffective means and vice versa. That is, whereas it may not be specially } \\
\text { suitable for the fulfilment of the legitimate objective, an inappropriate means may nevertheless be effective in fulfilling that objective, } \\
\text { despite its "unsuitability". Conversely, when a relevant international standard is found to be an effective means, it does not automatically } \\
\text { follow that it is also an appropriate means. The question of effectiveness bears upon the results of the means employed, whereas the } \\
\text { question of appropriateness relates more to the nature of the means employed."119 }\end{array}$ \\
\hline
\end{tabular}

${ }^{112} \mathrm{WT} / \mathrm{DS} 381 / \mathrm{AB} / \mathrm{R}$, paragraph 392. Original footnote removed.

${ }_{113} \mathrm{WT} / \mathrm{DS} 381 / \mathrm{AB} / \mathrm{R}$, paragraph 360.

${ }_{114}$ WT/DS381/AB/R, paragraph 394

115 WT/DS381/AB/R, paragraph 390.

116 WT/DS381/AB/R, paragraph 372.

117 WT/DS231/AB/R, paragraph 243.

${ }_{118} \mathrm{WT} / \mathrm{DS} 231 / \mathrm{AB} / \mathrm{R}$, paragraph 245.

$119 \mathrm{WT} / \mathrm{DS} 231 / \mathrm{R}$, paragraph 7.116. 